\title{
Tectonics
}

\author{
RESEARCH ARTICLE \\ 10.1029/2019TC005589 \\ Key Points: \\ - The Central Qiangtang \\ metamorphic belt is more likely to \\ be formed by the northward \\ subduction of the Longmu \\ Co-Shuanghu Tethys Ocean \\ - The late Paleozoic-Triassic \\ deposition in the southern North \\ Qiangtang block resembles that of a \\ forearc basin \\ - The detrital zircon age distributions \\ of the North Qiangtang block \\ constrain the northern boundary of \\ the Gondwanan realm to the north
}

Supporting Information:

- Supporting Information S1

Correspondence to:

$\mathrm{X}$. Liang,

liangx@cugb.edu.cn

Citation:

Liang, X., Sun, X., Wang, G., Gao, J., \& An, X. (2020). Sedimentary evolution and provenance of the late Permianmiddle Triassic Raggyorcaka deposits in North Qiangtang (Tibet, Western China): Evidence for a forearc basin of the Longmu Co-Shuanghu Tethys Ocean. Tectonics, 39, e2019TC005589. https://doi.org/10.1029/2019TC005589

Received 21 MAR 2019 Accepted 30 SEP 2019

Accepted article online 24 OCT 2019

\section{Sedimentary Evolution and Provenance of the late Permian-middle Triassic Raggyorcaka Deposits in North Qiangtang (Tibet, Western China): Evidence for a Forearc Basin of the Longmu Co-Shuanghu Tethys Ocean}

\author{
Xiao Liang ${ }^{1,2}$ (D), Xihui Sun ${ }^{1}$, Genhou Wang ${ }^{1}$ (D) Jinhan Gao ${ }^{1}$, and Xingyu An ${ }^{1}$ \\ ${ }^{1}$ School of Earth Sciences and Resources, China University of Geosciences (Beijing), Beijing, China, ${ }^{2}$ Structure Tectonics \\ Team, Research School of Earth Sciences, The Australian National University, Canberra, ACT, Australia
}

Abstract The tectonic origin of the $>500-\mathrm{km}$-long E-W trending Central Qiangtang metamorphic belt (CQMB), which separates the North Qiangtang block (NQB) and South Qiangtang block (SQB), remains controversial. Moreover, the coeval geological evolution of the southern NQB has been poorly investigated, particularly its tectonic relationship with the CQMB. Here we present stratigraphic, sedimentary, and provenance analyses of the late Permian-middle Triassic depositional succession at Raggyorcaka in the southern NQB and test two radically different hypotheses for origin of the CQMB. A complete marine transgression-regression sequence with two-sided provenance characterizes the late Permian-Triassic sedimentary rocks in the southern NQB. Sandstone petrological analyses reveal a prominent provenance transition to an active volcanic source beginning in the late Changhsingian. Detrital zircon $\mathrm{U}-\mathrm{Pb}$ geochronological results of the transgression subsequence show a concentrated youngest zircon group of $236-288 \mathrm{Ma}$ (peak at $248.1 \mathrm{Ma}$ ), with negative $\varepsilon \mathrm{Hf}(t)$ values $(-25.3$ to -0.2$)$ and large Hf crustal model ages $\left(T_{\mathrm{DM}}^{\mathrm{C}} ; 1,311-2,887 \mathrm{Ma}\right)$. These new findings show that the Raggyorcaka sequence was most likely deposited in an active continental margin. Combined with other evidence, we further infer that the Carboniferous-Triassic successions of the southern NQB were most likely deposited in a forearc basin under the in situ suture model, that is, the northward subduction of the Longmu Co-Shuanghu Tethys Ocean beneath the NQB. Moreover, the detrital zircon age distribution of the southern NQB suggests that the NQB probably drifted from the Gondwana supercontinent in the early Paleozoic and became adjacent to peri-Cathaysian blocks no later than the Carboniferous.

\section{Introduction}

The Tibetan Plateau hosts the largest and highest mountain chain on Earth (Searle et al., 2011; Yin \& Harrison, 2000). Recent geological, geophysical, and thermochronological studies suggest that its growth is correlated not only with the Cenozoic India-Asia collision but also with the Mesozoic orogeny within the interior of the plateau, which established the initial boundary conditions for Cenozoic uplift (Leier et al., 2007; Kapp et al., 2003, 2007; Pullen et al., 2008, 2011; Pan et al., 2012; Yin \& Harrison, 2000; Zhu et al., 2013). The $>500-\mathrm{km}$-long and up to 100-km-wide E-W trending Central Qiangtang metamorphic belt (CQMB; Figure 1) has been identified as an independent early Mesozoic tectonic terrane (Kapp et al., 2000, 2003; Liang et al. 2012, 2017; Pullen et al., 2008, 2011; Pullen \& Kapp, 2014; Yin \& Harrison, 2000; Zhao et al., 2015), which separated two distinct sedimentary depressions after the Triassic, namely, the North Qiangtang block and South Qiangtang block (NQB and SQB, respectively; Wang, \& Yin 2001; Wang et al., 2004). It is a central uplift/crustal antiformal culmination based on structural interpretations of geophysical data along a N-S trending transection across Qiangtang (Gao et al., 2013; Lu et al., 2001; Lu et al., 2013; Shi et al., 2004; Wei et al., 2001; Zhao \& Li, 2000). The CQMB is widely considered to record a portion of the Phanerozoic evolution of the eastern Paleo-Tethys Ocean, particularly the tectonics associated with oceanic subduction (Kapp et al., 2000, 2003; Li et al., 1995; Li, Chen, et al., 2006; Li, Huang, 2006; Li, et al., 2016; Liang et al., 2012, 2017; Pullen et al., 2008, 2011; Pullen \& Kapp, 2014; Yin \& Harrison, 2000; Zhai, Zhang, et al., 2011; Zhai, Jahn, et al., 2011; Zhai, Jahn, Su, Ernst, et al., 2013;Zhai, Jahn, Wang, et al., 2013; Zhai, et al., 2016;
(C)2019. American Geophysical Union. All Rights Reserved. 


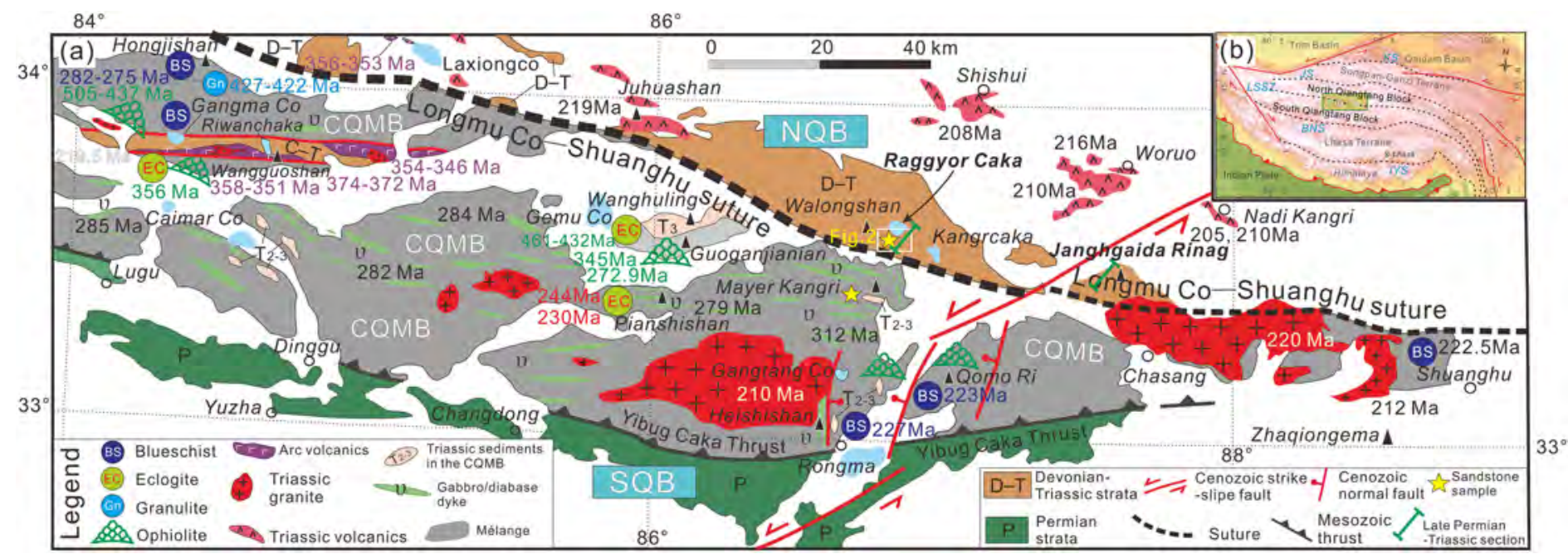

Figure 1. Geological map of Central Qiangtang with an emphasis on pre-Jurassic evolution and the tectonic architecture of the Tibetan Plateau. (a) The newly updated geological framework in Central Qiangtang. Three tectonic units could be identified across the LSSZ, including the NQB late Paleozoic-Triassic sedimentary succession and arc volcanics, the CQMB, and the SQB Permian sedimentary rocks. The lithological constitution of the CQMB and two suites of magmatic rocks are highlighted. (b) Color-shaded relief map of the Tibetan Plateau showing the study area, main suture zones, and large-scale faults. Abbreviations: LSSZ = Longmu Co-Shuanghu suture zone; KS = Kunlun suture; JS = Jinsha suture; BNS = Bangong-Nujiang suture; IYS = Indus-Yarlung Zangbo suture.

Zhang et al., 2016) and the amalgamation of individual blocks (Li et al., 1995; Li, Chen, et al., 2006; Li, Huang, 2006; Li, et al., 2016; Liang et al., 2012; Wang et al., 2018; Zhao et al., 2015).

Two major hypotheses have been proposed to explain the tectonic origin of the CQMB: (1) The CQMB was an allochthonous complex that originated from the $200 \mathrm{~km}$ southward underthrust of the Songpan-Ganzi flysch/Paleozoic arc terrane beneath a unified Qiangtang block and was subsequently exhumed by extensional detachment faults in the late Triassic-early Jurassic (Yin \& Harrison, 2000; Kapp et al., 2003; Pullen et al., 2008, 2011; Pullen \& Kapp, 2014), and (2) the CQMB was an accretionary complex of an in situ suture attributed to the northward subduction of the Longmu Co-Shuanghu Tethys Ocean beneath the NQB in the late Paleozoic-middle Triassic (Li, 1987; Li et al., 1995, 2016, 2019; Li, Zhai, Dong, et al., 2006; Li, Zhai, Chen, et al., 2006; Li, Chen, et al., 2006; Li, Huang, et al., 2006; Liang et al., 2012, 2017; Wang et al., 2009, 2017; Zhang, Cai, et al., 2006, Zhang, Zhang, et al., 2006; Zhai, Zhang, et al., 2011; Zhai, Jahn, et al., 2011; Zhai, Jahn, Wang, et al., 2013, 2016; Zhang, Cai, et al., 2006; Zhang, Zhang, et al., 2006). The allochthonous complex model was the first model indicating that the high-pressure and low-temperature (HP-LT) metamorphic rocks in the CQMB were exhumed from mantle depths by a crustal-scale detachment fault, and this finding was later corroborated by structural mappings (Liang et al., 2017; Zhao et al., 2015). In the in situ suture model, a long-lived early Paleozoic-Triassic ocean or the main branch of the PaleoTethys Ocean separated the NQB, which showed a Cathaysian affinity from the SQB, which showed a Gondwana affinity (Li, 1987; Li et al., 1995; Li, Zhai, Dong, et al., 2006; Li, Zhai, Chen, et al., 2006; Li, Chen, et al., 2006; Li, Huang, et al., 2006; Li, Zhai, Chen, et al., 2007, 2016; Liu et al., 2002). This inference is based on the Paleozoic-early Triassic ophiolite suites discovered within the hanging wall of the detachment fault (Li et al., 1995; Li, Chen, et al., 2006; Li, Huang, et al., 2006, 2016; Zhu et al., 2006; Wang, Pan, et al., 2008; Wu et al., 2010; Zhai, Jahn, Wang, et al., 2013, 2016; Zhang et al., 2017; Fan et al., 2017) and the distinct stratigraphy and biota in the two blocks (Li, 1987; Li et al., 1995; Li, Chen, et al., 2006; Li, Huang, et al., 2006, 2016; Liu et al., 2002; Metcalfe, 2013). The in situ suture model is also supported by the observation that the CQMB features multistage penetrative deformations associated with oceanic subduction and the ensuing late Triassic-early Jurassic continental collision between the NQB and SQB (Liang et al., 2012, 2017; Li et al., 2019; Wang et al., 2018; Zhao et al., 2015). In the past, the NQB was thought to be derived from the Cathaysian realm (Li et al., 1995; Li, Chen, et al., 2006; Li, Huang, et al., 2006; 2016). However, this concept has been largely refuted based on careful interpretation of paleontological data (Pullen \& Kapp, 2014; Song et al., 2017) and detrital zircon provenance data (Gehrels et al., 2011; Kapp et al., 2003; Pullen et al., 2008). 


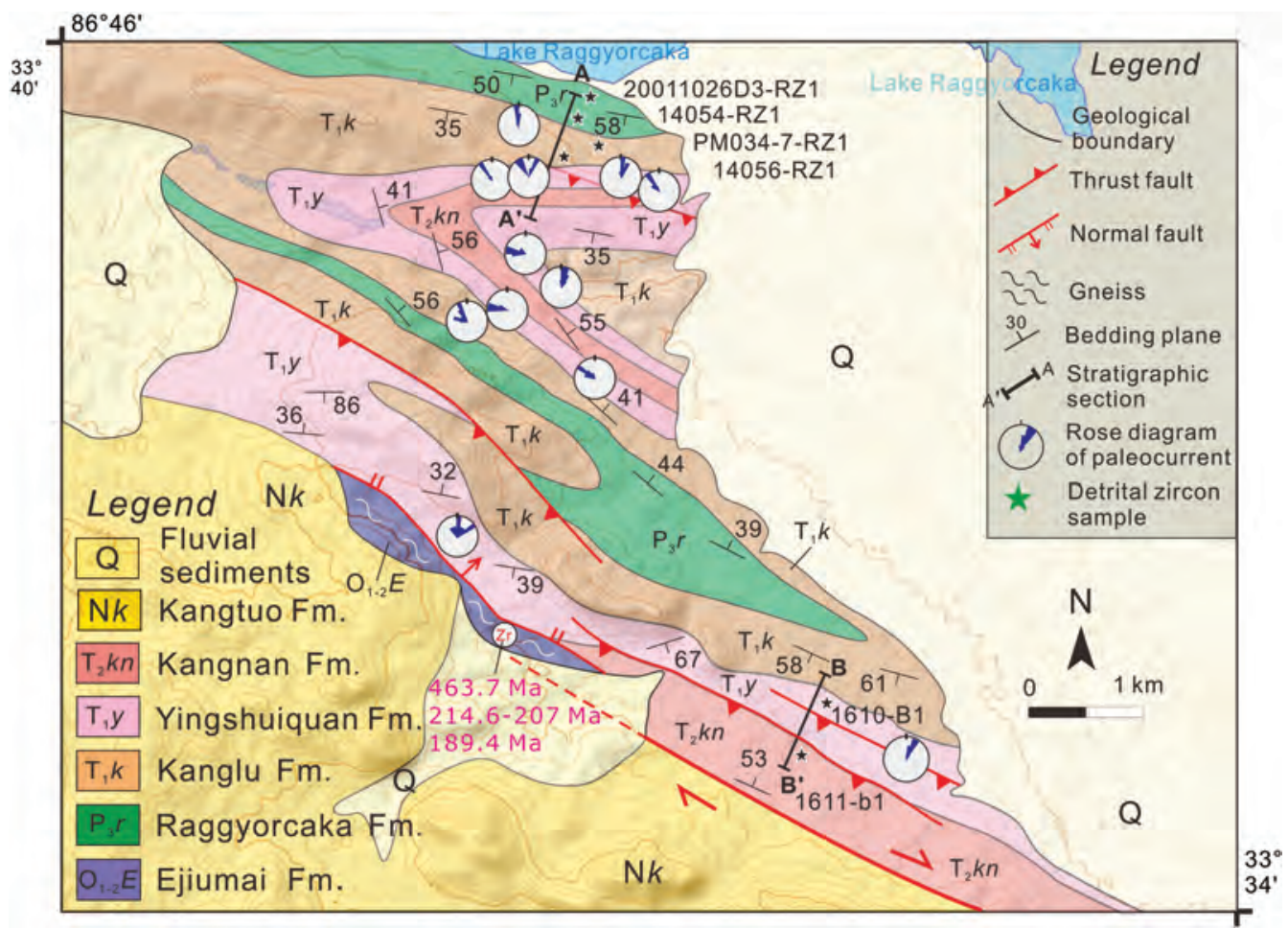

Figure 2. Detailed geological map showing the distribution of the pre-Jurassic strata and their structural styles in Raggyorcaka of the southern North Qiangtang block (Map data: Open Topo Map image from the Global Mapper). The late Permian-Middle Triassic sedimentary rocks are intensively deformed by multistage folds and thrust faults (cf. Liang et al., 2015). The locations of sedimentary structures, two stratigraphic sections, and the sandstone samples are indicated on the rose diagram.

Numerous studies have investigated the CQMB, especially the Permian (283-259 Ma) and Triassic (244$211 \mathrm{Ma}$ ) HP-LT metamorphic rocks (Figure 1; Deng et al., 2000; Kapp et al., 2003; Li et al., 1995; Li, Zhai, Dong, et al., 2006; Li, Zhai, Chen, et al., 2006; Liang et al., 2012, 2017; Yin \& Harrison, 2000; Zhao et al., 2014, 2015; Zhang et al., 2017) and Paleozoic-early Triassic ophiolites (Li et al., 1995; Li, Chen, et al., 2006; Li, Huang, et al., 2006, 2016; Zhu et al., 2006; Wang, Pan, et al., 2008; Wu et al., 2010; Zhai, Jahn, Wang, et al., 2013, 2016; Zhang et al., 2017). In contrast, the southern margin of the NQB, especially the late Paleozoic-Triassic sedimentary evolution and its tectonic relationship with the CQMB, remains poorly studied. Previous works were implemented to address the stratigraphic framework (Chen et al., 2009; Li, Huang, et al., 2006; Li et al., 2016; Wu et al., 2009; Zhang et al., 2015; Zhu et al., 2005, 2010) and the general sedimentary environment and the provenance (Gehrels et al., 2011; Xie et al., 2018). Additionally, no coeval arc-relevant magmatic rocks that coincide with the peak metamorphism of the HP-LT rocks have been discovered in the NQB.

Here, we perform an integrated sedimentary study of the late Paleozoic-Triassic strata in the southern NQB to better understand the large-scale subduction-related tectonics. The Raggyorcaka in the southern NQB is situated immediately to the north of the CQMB (Liang et al., 2015). The region has extraordinary outcrops of a continuous late Permian-middle Triassic sedimentary sequence (Figures 2, 4, and 5). Our investigation of this sequence includes studies of stratigraphy, sedimentary facies, and paleocurrent direction and provenance studies based on sandstone petrology, detrital zircon $\mathrm{U}-\mathrm{Pb}$ geochronology, and Hf isotopic geochemistry. Our new data and a compilation of results of the Carboniferous-Triassic strata in the southern NQB are used to (1) infer the late Paleozoic-Triassic sedimentary evolution of the southern NQB, (2) test the two opposing hypothetical models, and (3) outline a preliminary Permo-Triassic paleogeography framework for Central Qiangtang.

\section{Geological Setting}

Geological mapping has shown that the CQMB is a typical "block in matrix" mélange (Kapp et al., 2000, 2003; Li et al., 2019; Liang et al., 2012, 2017; Pullen et al., 2008, 2011; Wang et al., 2009; Wang et al., 
2018). Polyphase foliated clastic rocks mainly consisting of late Carboniferous-Permian submarine siliciclastic flysch (Liang et al., 1983; Li et al., 1995; Li, Chen, et al., 2006; Li, Huang, et al., 2006) surround many other blocks, including Permian-Triassic HP-LT metamorphic rocks (Deng et al., 2000; Kapp et al., 2000, 2003; Li et al., 1995; Li, Zhai, Dong, et al., 2006; Li, Zhai, Chen, et al., 2006; Liang et al., 2012, 2017; Pullen et al., 2008; Yin \& Harrison, 2000; Zhao et al., 2014, 2015; Zhang et al., 2017), a late Carboniferous-early Permian gabbro dyke swarm (Li, Chen, et al., 2006; Zhai, Jahn, Su, Ernst, et al., 2013), Paleozoic ophiolite relics (Li et al., 1995; Li, Chen, et al., 2006; Li, Huang, et al., 2006, 2016; Wang, Pan, et al., 2008; Wu et al., 2010; Zhai, Jahn, Wang, et al., 2013, 2016; Zhang et al., 2017; Zhu et al., 2006), Permian-early Triassic oceanic island/seamount slices (Fan et al., 2017; Y. C. Zhang, Shen, et al., 2012), middle-late Triassic abyssal sedimentary rocks (Deng et al., 1996; Li et al., 1997), and Ordovician quartzite and limestone slices (Dong et al., 2011; Li, Chen, et al., 2006, 2016). The CQMB is characterized by a low-grade metamorphism and ductile deformation in the form of early penetrative E-W shearing fabrics and later N-S compressional structures (Liang et al., 2012, 2017; Li et al., 2019; Wang et al., 2018). The CQMB is separated by an angular unconformity from the overlying upper Triassic neritic carbonate and clastic rocks of the Wanghuling Formation (Figure 1a) (Ji et al., 2010; Li, Zhai, Dong, et al., 2007). Additionally, intense intermediate to acidic plutonism occurred within the CQMB as shown by the Bensong Co-Gangtang Co-Shuanghu giant porphyritic granite that formed at 220-210 Ma (Figure 1a; Kapp et al., 2003; G. M. Li, Li, et al., 2015; J. C. Li, Zhao, et al., 2015). Since the Jurassic, the CQMB has been a topographical high separating two different suites of thick Jurassic marine-dominant sedimentary rocks, which were then unconformably overlain by Cretaceous-Cenozoic red terrestrial clastic-dominated rocks (Wang, \& Yin, 2001; Wang et al., 2004).

The Carboniferous-Permian bathyal clastic and carbonate sedimentary rocks in the SQB have a Gondwana affinity as indicated by the cold-water bivalve and brachiopoda fauna (Liang et al., 1983; Li, Chen, et al., 2006; Li, Huang, et al., 2006, 2016), glaciomarine diamictite (Fan et al., 2015; Li, 1987; Liang et al., 1983) and similar detrital zircon age spectrum as the Tethys Himalaya (Dong et al., 2011; Fan et al., 2015; Kapp et al., 2003; Pullen et al., 2008; Zhao et al., 2014). The carbonate rocks have both cold- and warm-water fauna starting in the early Permian (Geng et al., 2012; Li, Chen, et al., 2006; Li, Huang, et al., 2006, 2016). In the Rongma area, the Paleozoic strata were unconformably overlain by late Triassic-Jurassic neritic to bathyal limestone-dominated sedimentary rocks.

In contrast, a fairly continuous sequence of littoral, neritic, and delta facies developed in the southern NQB from the Devonian to the late Triassic (Li, Chen, et al., 2006, 2016; Wang, \& Yin, et al., 2001; Wang et al., 2004). Furthermore, the newly discovered late Devonian-early Carboniferous (374-346 Ma) Wangguoshan volcanic rocks have been shown to be in conformable contact with other strata in the NQB (Jiang et al., 2015; Li et al., 2016; Wang et al., 2017). Notably, abundant warm-water fauna, especially coral and fusulinid assemblages, are continuously present in the middle Devonian carbonate and overlying rocks. Biota with a typical Cathaysian affinity, such as Carboniferous coral and fusulinid fauna (Cheng et al., 2006; Li et al., 2016; Wu et al., 2009) and late Permian Changhsingian Gigantopteris flora and fusulinid fauna, have been found (Figures 1 and 2; Chen et al., 2006, 2009; Li, Chen, et al., 2006; Liu \& Sun, 2008 and references therein; Zhang et al., 2015). A late Triassic angular unconformity exists between the thick middle-late Triassic carbonate and clastic rocks and the overlying late Triassic Nadi Kangri intermediate-acidic volcanic rocks (Wang et al., 2007; Wang, Fu, et al., 2008; Fu et al., 2010; Zhang et al., 2011; Zhai, Jahn, Su, Wang, et al., 2013). Nadi Kangri volcanic rocks with ages of 223 to $202 \mathrm{Ma}$ (Fu et al., 2010; Wang et al., 2007; Wang, Fu, et al., 2008; Zhang et al., 2011; Zhai, Jahn, Su, Wang, et al., 2013) and their counterparts within the CQMB, for example, the 220- to 210-Ma Bensong Co-Gangtang Co-Shuanghu granite (Kapp et al., 2003; G. M. Li, Li, et al., 2015 ; J. C. Li, Zhao, et al., 2015; Wu et al., 2015), postdate the peak metamorphism of the 244- to 232-Ma HP-LT metamorphic rocks (Li, Zhai, Chen, et al., 2006; Liang et al., 2012; Kapp et al., 2003; Pullen et al., 2008; Zhai, Zhang, et al., 2011).

\section{Methods}

To study the sedimentological evolution of the late Permian-middle Triassic deposits at Raggyorcaka in the NQB, we measured two stratigraphic sections (A- $\mathrm{A}^{\prime}$ and $\mathrm{B}-\mathrm{B}^{\prime}$ in Figure 2) and conducted a comprehensive investigation examining the stratigraphy, sedimentology, and provenance. 


\section{Raggyorcaka(P3-T3)}

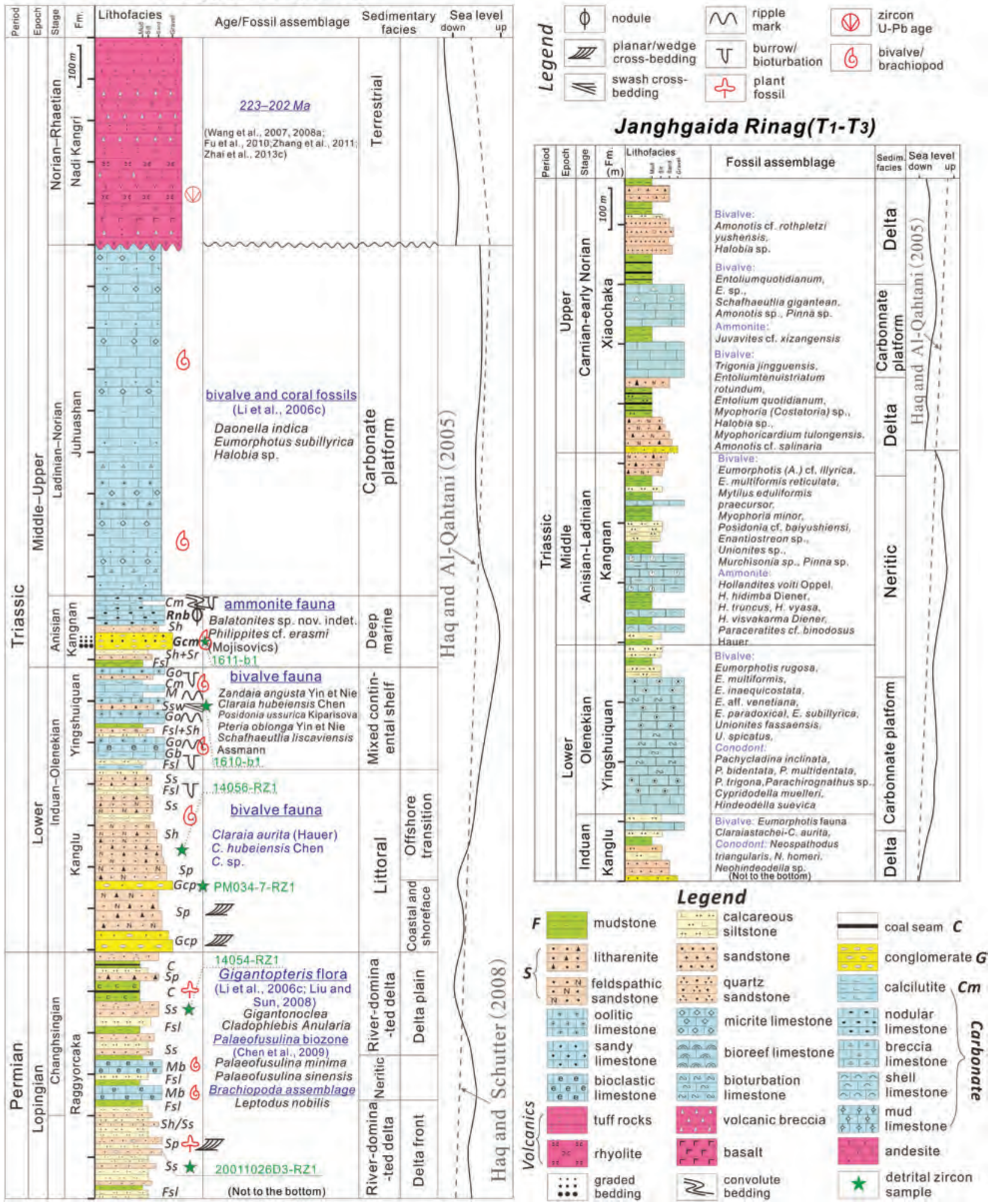

Figure 3. The integrated stratigraphic columns for the late Permian-Triassic deposits of Raggyorcaka and Triassic deposits of Janghgaida Rinag, respectively. Depositional characteristics such as lithofacies, index fossil assemblage, sedimentary environment, and the relative sea level change are individually displayed. The diagrams of the Middle-Late Triassic Juhuashan and late Triassic Nadi Kangri Formations were modified from Li, Chen, et al., (2006), (2016) and Wang et al., (2007), Wang, Fu, et al., (2008), respectively. Note that the global eustatic curve (based on Haq \& Al-Qahtani, 2005; Haq \& Schutter, 2008; Guillaume et al., 2016) was also included to make a comparison. 
Table 1

Facies Association of the late Permian-middle Triassic Raggyorcaka Sedimentary Succession

\begin{tabular}{|c|c|c|c|c|}
\hline Age & Formation & Facies & Subfacies & Lithofacies \\
\hline \multirow[t]{2}{*}{ Middle Triassic } & Kangnan Fm. & Deep marine & Slumping deposits & $\mathrm{Rbn}, \mathrm{Cm}$ \\
\hline & & & Submarine fan & Gcm, Sh, Sr, Fsl \\
\hline \multirow[t]{6}{*}{ Early Triassic } & Yingshuiquan Fm. & Clastic continental shelf & Shelf interior & Fsl, Sh \\
\hline & & & Shoal & Ssw \\
\hline & & Carbonate platform & Carbonate platform interior & $M, G b$ \\
\hline & & & Shoal & Go \\
\hline & Kanglu Fm. & Littoral & Offshore transition & Ss, Sh, Fsl \\
\hline & & & Coastal and shoreface & $G c p, S p$ \\
\hline \multirow[t]{4}{*}{ Late Permian } & Raggyorcaka Fm. & Delta & Delta plain & $C, F s l, S p, S s$ \\
\hline & & Shallow marine & Shelf & Fsl \\
\hline & & & Carbonate platform & $M b$ \\
\hline & & Delta & Delta front & $F s l, S s, S h, S p$ \\
\hline
\end{tabular}

Note. See Table S1 for explanation of lithofacies.

\subsection{Stratigraphy and Sedimentology}

According to Liang et al. (2015), the structural style of the late Permian-Middle Triassic strata at Raggyorcaka is characteristic of the superimposition of three-phase buckle folds; among them, the Early Cretaceous ESE-plunging (20-30 $)$ upright folds and concomitant thrusts dominate (Figure 2). The two studied outcrop sections both are well exposed. A continuous sedimentary sequence of the Raggyorcaka, Kanglu, Yingshuiquan, and Kangnan formations is preserved in Section A-A'. However, only the Kangnan Formation is continuous in Section B- $\mathrm{B}^{\prime}$ due to truncation and displacement by the WNW trending thrust faults (Figure 2).

We conducted lithofacies analyses and collected numerous index fossils to ascertain the stratigraphic age of each formation. The sedimentary facies were assessed based on their lithofacies, fossil assemblages, and sedimentary structures (Figure 3). The terms and codes (Table 1 and supporting information Table S1) used to describe the lithofacies and the depositional environment of the continental and marine siliciclastic rocks in this paper generally follow those of Miall (1978, 1985), DeCelles et al. (1991, 2007), and Liu and Wang (2001). For marine carbonate rocks, the lithofacies codes and the interpretations are mainly after Tucker (2011). The classification schemes for turbidite and submarine fans by Bouma (1962) and Walker (1978) are also used.

\subsection{Paleocurrent Direction}

Marine-terrigenous deposits characterize the investigated late Permian-middle Triassic strata at Raggyorcaka. We use sedimentary structures with unambiguous paleocurrent flowing directions to infer the detrital provenance. These structures include tabular and wedge cross beddings in the coarse-grained sandstone layers in the lower Kanglu Formation (Figures 4e and 4f) and the asymmetric ripple marks in the oolitic limestone beds in the Yingshuiquan Formation (Figures $4 \mathrm{~d}$ and $4 \mathrm{i}$ ). For the ripple marks, we assume that the dip direction of the short side indicates where the terrigenous paleocurrent is from.

Accordingly, the inner laminae of the cross beddings, the shorter side of ripple marks, and the bedding planes of beds were measured. Only ripple marks bearing either a flat-topped crest or abundant shell swarms within the wave trough were chosen for attitude measurement and statistical analysis. Ultimately, we rotated the inclined bedding planes to horizontal using Stereonet 7 (Allmendinger et al., 2012) to eliminate the effect of the superimposed folds (Figure 7) and thereby recover the original attitudes of the analyzed structures (Table S2). We interpreted the paleocurrent direction in terms of dip direction rose diagrams and attitude stereographic projections in Wulff net by Stereonet 7 (Allmendinger et al., 2012).

\subsection{Provenance}

\subsubsection{Sandstone Petrological Analyses}

Fifty-one sandstone samples with matrix contents less than $15 \%$ were collected from the lower Raggyorcaka Formation to the Kangnan Formation, including 49 samples from Section A-A' and 2 from Section B-B' (Figure 2). Grain composition statistics ( $\geq 350$ framework counts per slide) were then obtained following the Gazzi-Dickinson method (Dickinson, 1985; Gazzi, 1966). The results of the modal analysis are 

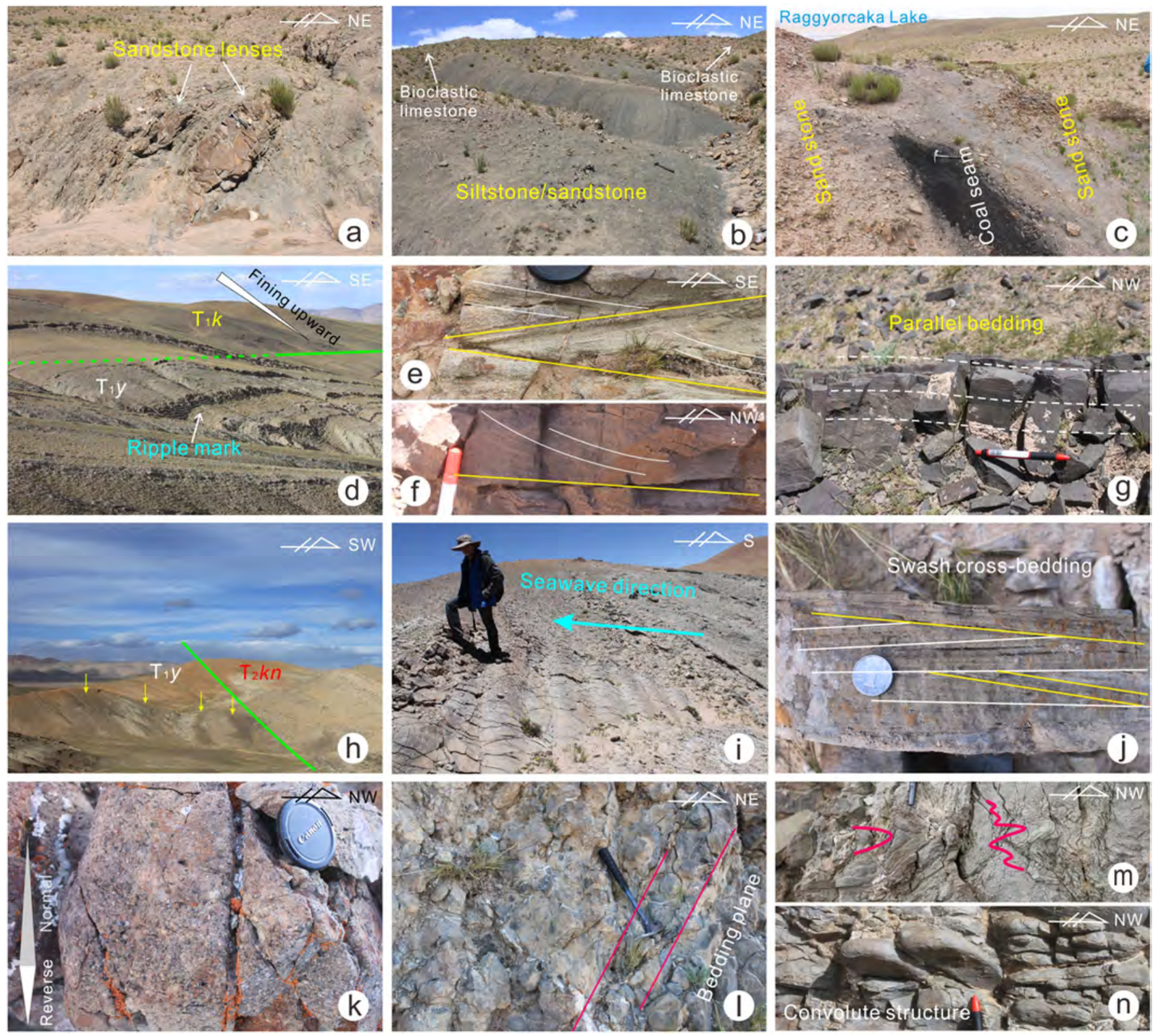

Figure 4. General lithofacies and sedimentary structures for each formation of late Permian-Middle Triassic sediments in Raggyorcaka. (a) Sheet-like and lenticular quartzose sandstone within siltstone (lower Raggyorcaka Formation). (b) Interlayered thin-bedded siltstone and sandstone within bioclastic limestone (middle Raggyorcaka Formation). (c) Coal seam interlayered within medium-grained sandstone (upper Raggyorcaka Formation). (d) Distinct lithofacies features of the Kanglu and Yingshuiquan Formations. (e, f) Wedge cross bedding of massive sandstone and planar cross bedding of conglomeratic sandstone on the bottom and lower parts, respectively, of the Kanglu Formation. (g) Parallel bedding within fine-grained sandstone. (h) Two different lithofacies suites of the Yingshuiquan and Kangnan Formations; the former consists of four sedimentary cycles including a clastic lower unit and carbonate upper unit. (i) Large ripple marks on oolitic limestone in the Yingshuiquan Formation. (j) Swash cross bedding within sandstone of the Yingshuiquan Formation. (k) Bidirectional graded bedding of finegrained conglomerate in the Kangnan Formation (section B-B'). (l) Nodular limestone in the Kangnan Formation. (m, n) Convolute bedding in the Kangnan Formation.

presented in Table S3 in the supporting information. For the provenance interpretation, we constructed ternary diagrams such as QFL, QmFLt, QpLvLs, and QmPK, according to Dickinson and Suczek (1979) using the routine Triplot.

3.3.2. Detrital Zircon Geochronological and Hf Isotopic Analyses

Six fresh sandstone samples were collected at Raggyorcaka (Figures 1 and 2) and subjected to detrital zircon $\mathrm{U}-\mathrm{Pb}$ geochronology using a laser ablation inductively coupled plasma mass spectrometry (see Text S1 for 
Table 2

The Calculation of Maximum Depositional Ages (MDAs) Using Different Methods for the Sandstone Samples from Raggyorcaka (The robust MDA candidates are highlightened in bold)

\begin{tabular}{llcrrrr}
\hline Sample no. & \multicolumn{1}{c}{ Formation } & Youngest single grain & Youngest peak age & Concordia intercept & YC1- $\sigma(2+)$ & YC2- $\sigma(3+)$ \\
\hline 1611-b1 & Kangnan Fm., $\left(\mathrm{T}_{2}\right)$ & $225.65 \pm 6.66$ & $256 \mathrm{Ma}$ & $\mathbf{2 4 5 . 1} \pm \mathbf{4 . 9}$ & $240.4 \pm 3.4$ & $\mathbf{2 4 4 . 2} \pm \mathbf{2 . 3}$ \\
1610-B1 & Yingshuiquan Fm., $\left(\mathrm{T}_{1}\right)$ & $238.57 \pm 5.28$ & $252 \mathrm{Ma}$ & $\mathbf{2 4 9 . 5} \pm \mathbf{3 . 7}$ & $\mathbf{2 4 9 . 5} \pm \mathbf{3 . 1}$ & $\mathbf{2 4 8 . 6} \pm \mathbf{3 . 0}$ \\
14056-RZ1 & Kanglu Fm., $\left(\mathrm{T}_{1}\right)$ & $242.08 \pm 4.81$ & $258.3 \mathrm{Ma}$ & $244.3 \pm 3.7$ & $244.3 \pm 3.4$ & $\mathbf{2 5 0 . 2} \pm \mathbf{2 . 0}$ \\
PM034-7 & Kanglu Fm., $\left(\mathrm{T}_{1}\right)$ & $246.19 \pm 2.09$ & $248.6 \mathrm{Ma}$ & $\mathbf{2 5 0 . 5} \pm \mathbf{1 . 6}$ & $247.9 \pm 1.2$ & $\mathbf{2 4 9 . 1} \pm \mathbf{1 . 0}$ \\
14054-RZ1 & Raggyorcaka Fm., $\left(\mathrm{P}_{3}\right)$ & $250.45 \pm 5.01$ & $255.8 \mathrm{Ma}$ & $257.2 \pm 6.5$ & $255.6 \pm 5.2$ & $\mathbf{2 5 4 . 5} \pm \mathbf{9 . 2}$ \\
20110626D3-RZ & Raggyorcaka Fm., $\left(\mathrm{P}_{3}\right)$ & $244.13 \pm 4.30$ & $251.6 \mathrm{Ma}$ & $\mathbf{2 5 3 . 3} \pm \mathbf{5 . 3}$ & $247.1 \pm 3.9$ & $250.7 \pm 2.2$ \\
\hline
\end{tabular}

the analytical procedures) to (1) determine the strata provenance (e.g., Orme et al., 2015; Orme \&Laskowski, 2016) and (2) estimate the maximum depositional ages (MDAs) of the samples using the weighted mean ages (WMAs) of the youngest U-Pb radiometric age populations (cf. Dickinson \& Gehrels, 2009). For comparison, a late Paleozoic quartz sandstone sample was collected at Mayer Kangri (Figure 1) for the study (Table S4).
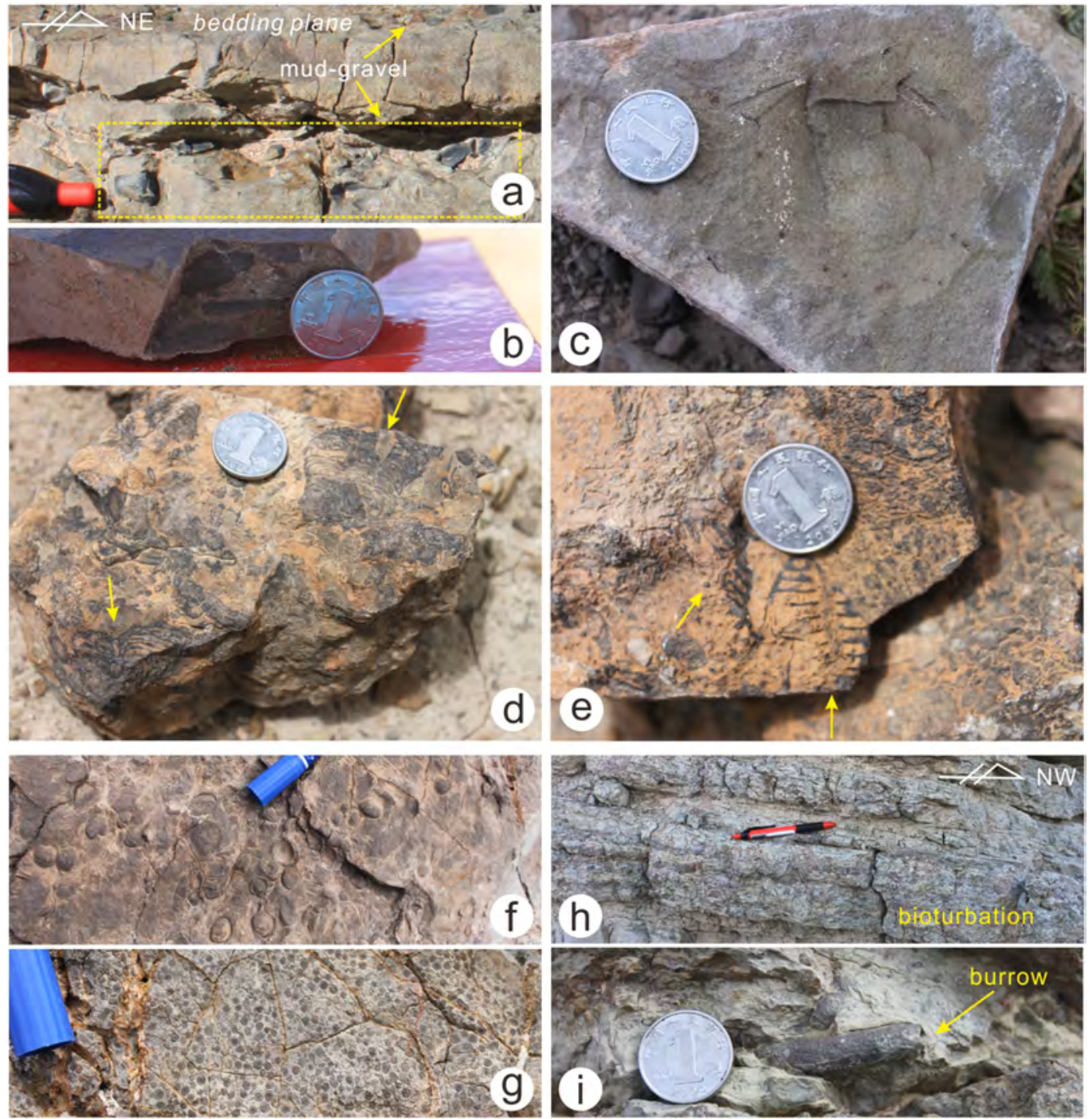

Figure 5. Guide fossils and typical lithofacies for each formation of Raggyorcaka late Permian-Middle Triassic deposits. (a, b) Mud gravel and carbonized plant debris within a large sandstone lens of the lower Raggyorcaka Formation. (c) Claraia mold fossils (early Triassic) preserved in sandstone of the upper Kanglu Formation. (d, e) Leptodus nobilis fossils (Changhsingian) retained within dark limestone layers of the middle Raggyorcaka Formation. (f, g) Shell mold fossils of oolitic limestone and pisolitic limestone in the Yingshuiquan Formation. (h, i) Intense bioturbation structure in calcilutite of the Kangnan Formation. 

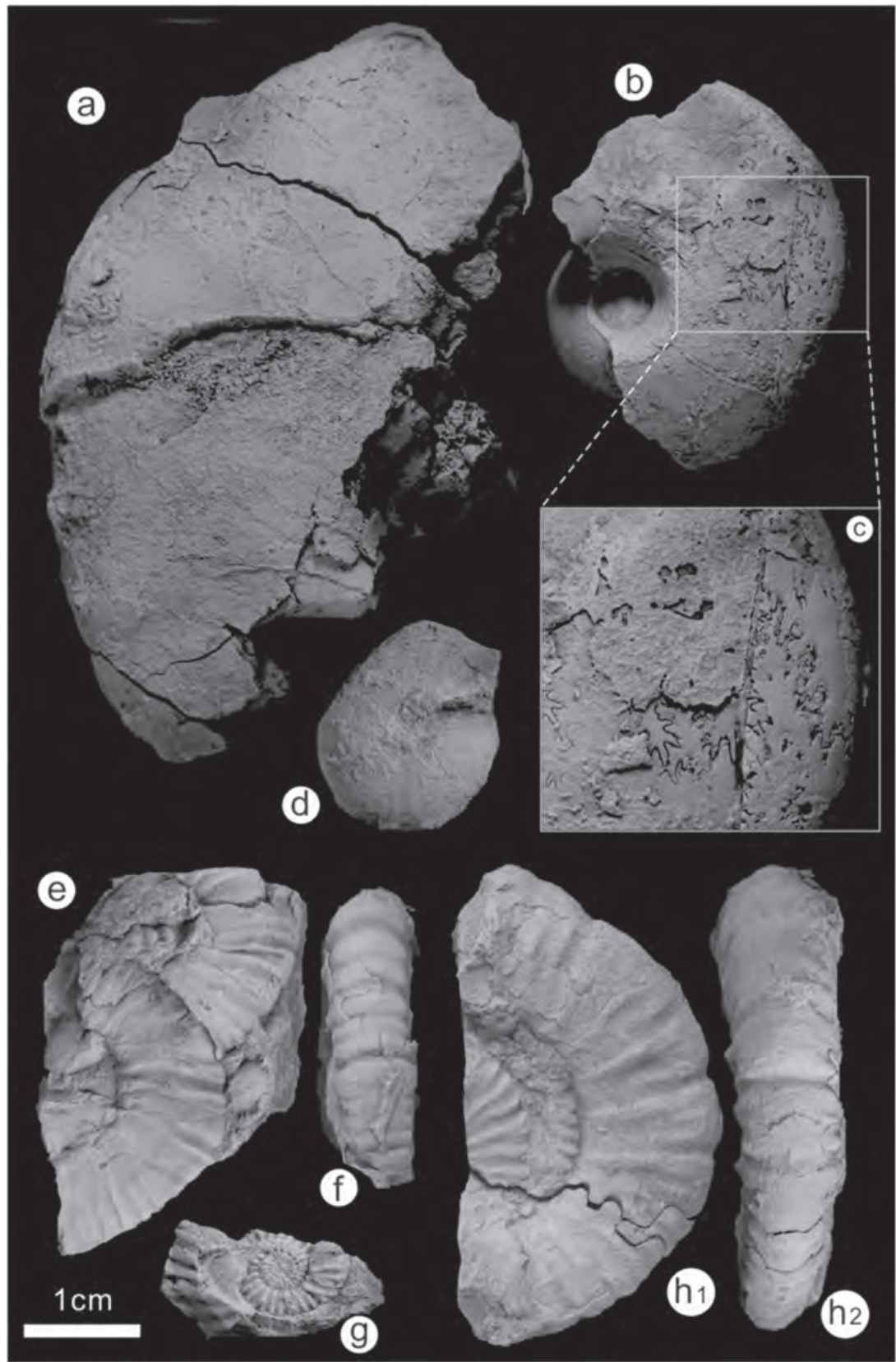

Figure 6. Scanning electron microscope images of the ammonite fossils collected in massive conglomeratic sandstone of the lower Kangnan Formation (section B-B '). (a-d) Philippites cf. erasmi (Mojisovics) and (e-h) Balatonites sp. nov. indet.

The acquired $\mathrm{U}-\mathrm{Pb}$ dating results show uncertainties at the $1 \sigma$ level and display measurement errors. ${ }^{206} \mathrm{~Pb} /$ ${ }^{238} \mathrm{U}$ and ${ }^{207} \mathrm{~Pb} /{ }^{206} \mathrm{~Pb}$ ages were used for individual zircon grains with ages of $<1,000 \mathrm{Ma}$ and $>1,000 \mathrm{Ma}$, respectively. In addition, discordance filters of $>90 \%$ and $>80 \%$ were adopted for zircon ages of $<1,000$ and >1,000 Ma, respectively (Table S4).

The MDAs are interpreted to be robust approximations of true depositional ages (TDAs) if the following two assumptions are met (cf.Orme et al., 2015 ; Sickmann et al., 2018): (1) There is continuous magmatism in the source area, and (2) the time gap between the magmatic crystallization ages of the zircons and the depositional ages of the strata is short. Although multiple statistical treatments were performed using Isoplot (Ludwig, 2008; cf. Dickinson \& Gehrels, 2009) to calculate each sandstone sample's MDA, the YC2- $\sigma(3+)$, which is the youngest cluster of three or more ages with overlapping $2 \sigma$ uncertainties, has been shown to 


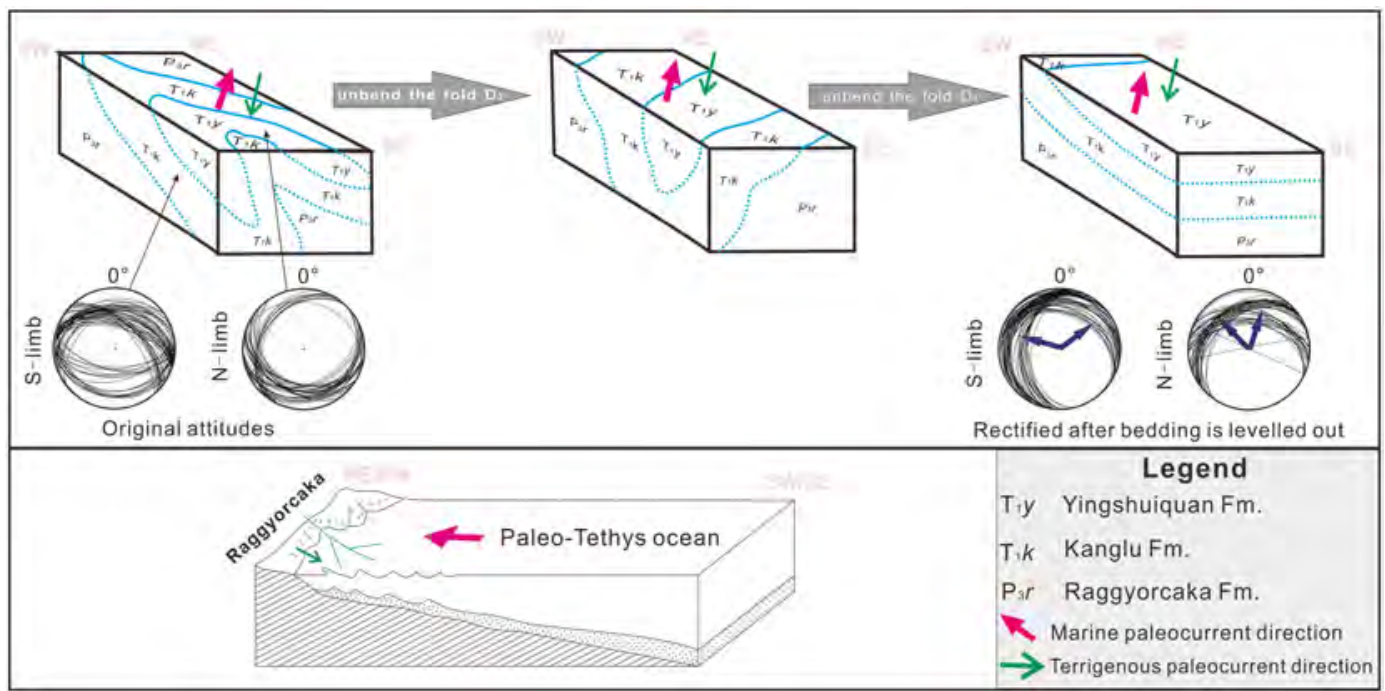

Figure 7. Schematic cartoons illustrating the estimations of the flowing directions of the paleocurrent. After unbending the two-staged superimposed buckle folds, we recovered the original attitudes of the strata for the Kanglu and Yingshuiquan Formations. The stereographic projections (using Stereonet 7 by Allmendinger et al., 2012) are the measured attitude data sets of both the inner tabulation of cross bedding and the shorter wings of the ripple marks.

be the most robust method (Orme et al., 2015; Sickmann et al., 2018). We used this algorithm and found that it produced reasonable results for the Raggyorcaka samples (Figures 3, S2, and S3 and Table 2).

Finally, to determine the magma source of the detrital zircon grains and perform a comparative study with the late Devonian to early Carboniferous arc rocks in Riwanchaka and Laxiongco, we conducted in situ zircon $\mathrm{Hf}$ isotope analyses of detrital zircons with ${ }^{206} \mathrm{~Pb} /{ }^{238} \mathrm{U}$ ages of $236-288 \mathrm{Ma}$. The same zircon grains from sample 14056-RZ1 (the top of the Kanglu Formation) used in the laser ablation inductively coupled plasma mass spectrometry dating analysis (Figure S1 and Table S4) were analyzed using a MC-ICP-MS (see analytical procedures in Text S1). Among the 35 zircon grains, 28 individual grains with normal $\mathrm{Lu}\left({ }^{176} \mathrm{Lu} /\right.$ $\left.{ }^{177} \mathrm{Hf}<0.0002\right)$ and $\mathrm{Yb}$ concentrations $\left({ }^{176} \mathrm{Yb} /{ }^{177} \mathrm{Hf}<0.05\right)$ were used to calculate the $\mathrm{Hf}$ isotopic compositions (Table S5).

\section{Results}

\subsection{Stratigraphy and Sedimentology}

\subsubsection{Lithofacies and Depositional Environment}

For the late Permian-early Triassic strata, including the Raggyorcaka, Kanglu, and Yingshuiquan Formations, the described sedimentary sequences are primarily based on Section A- $\mathrm{A}^{\prime}$; a necessary comparison was also made with that of Section B-B' (Figure 2). In contrast, we present the lithofacies and sedimentary facies for the middle Triassic Kangnan Formation mainly according to Section B-B'.

\subsubsection{Raggyorcaka Formation}

Description. The Raggyorcaka Formation consists of three distinct sedimentary units (Figure 3). The lower unit consists predominantly of dark gray siltstone, silty mudstone (lithofacies Fsl) and light gray to gray sandstone. The sandstone layers occur in either sheet-like or lentoid forms (Figure 4a), with the latter form always exhibiting a convex bottom and a planar top. Parallel bedding structures were found within the sheet-like sand bodies ( $\mathrm{Sh} / \mathrm{Ss})$, while planar cross beddings, dark mudstone gravel, and fossil stems were preserved within sandstone lenses (Sp; Figures $5 \mathrm{a}$ and $5 \mathrm{~b}$ ). The sandstone layers initially show upward increase in the frequency, bed thickness, and grain size, which then decrease at the top part (Figure 3). The middle part features interbedded medium-thick, medium- to coarse-grained sandstone and siltstone.

Dark gray or black thin- to medium-bedded bioclastic limestone $(\mathrm{Mb})$ characterizes the middle unit (Figure 4b). The limestone contains abundant fossils, including brachiopods (Figures $5 \mathrm{~d}$ and $5 \mathrm{e}$ ), fusulinids, and foraminiferans. It also contains many 1 - to 2 -cm-thick layers of very fine grained sandstone and silty 


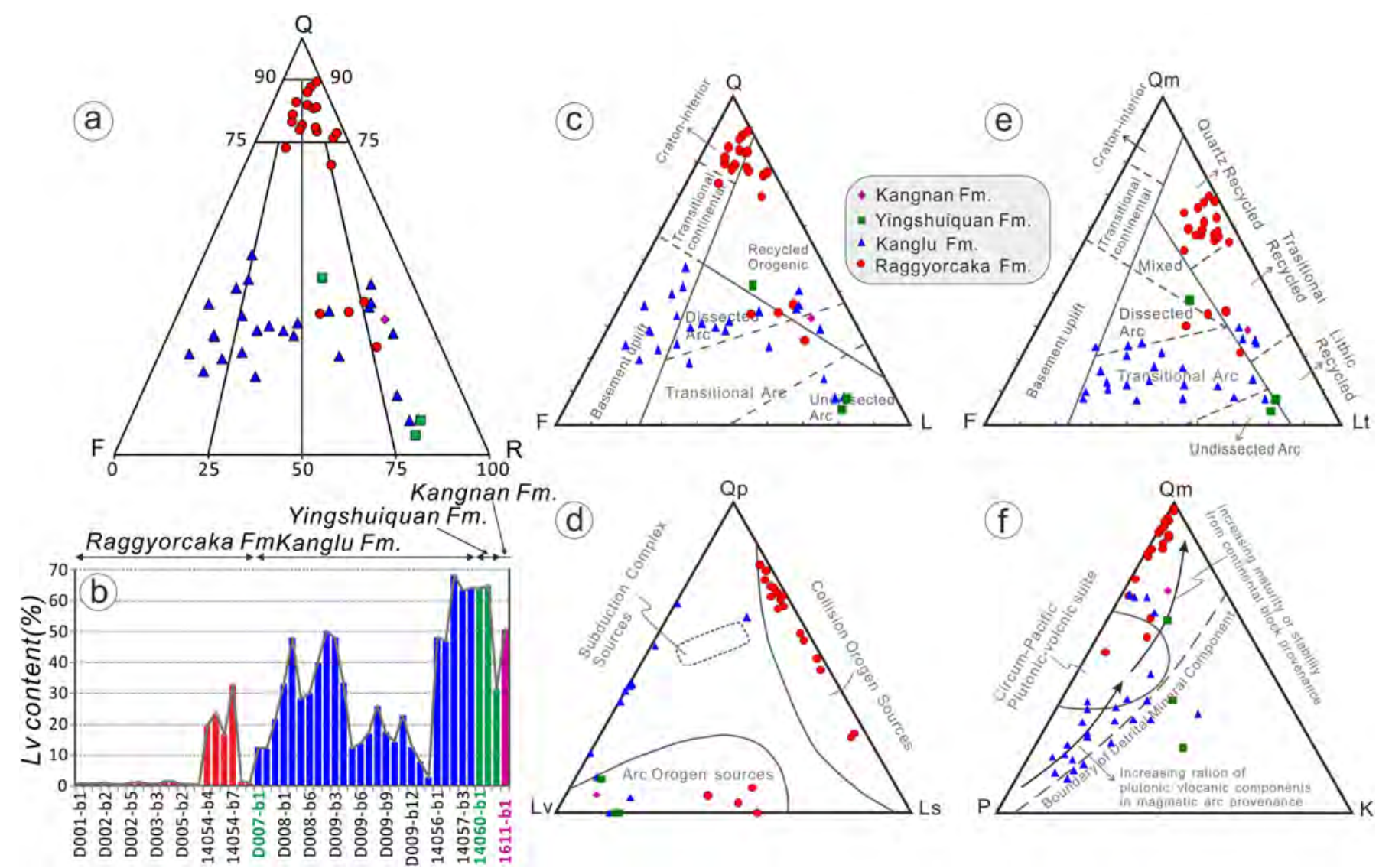

Figure 8. Ternary diagrams and histogram showing sandstone composition variations of the late Permian-Middle Triassic marine transgressive sequence in Raggyorcaka. (a) QFR ternary diagram showing the compositional classification of Raggyorcaka sandstone samples (the base diagram is based on Folk et al., 1970). (b) Histogram displaying the variation in volcanic debris (Lv) composition for sequentially collected sandstone samples. (c-f) Ternary diagrams showing the modal framework grain compositions of sandstones (the base diagrams are based on Dickinson \& Suczek, 1979 and Dickinson et al., 1983). Q represents the total quartzose grains, including monocrystalline Qm and polycrystalline Qp varieties; F represents the total monocrystalline feldspar grains; L represents the total unstable polycrystalline lithic fragments, including Lv (total volcanic rock fragments) and Ls (total sedimentary rock fragments); Lt represents the total polycrystalline lithic fragments, including stable quartzose $(\mathrm{Qp})$ and unstable (L) varieties; F represents plagioclase feldspar grains; and $\mathrm{K}$ represents k-feldspar grains.

mudstone (Fsl; Figure 4b). The upper unit of the Raggyorcaka Formation mainly consists of alternating thin to medium beds of gray mudstone and siltstone (Fsl) and medium-grained sandstone (Ss/Sp; Figure 4c). Notably, up to six coal seams that are less than 1-m-thick each contain abundant plant fossils (lithofacies C) at the top (Figure 4c).

Facies interpretation. A deltaic environment is indicated by the stacking pattern of the lower unit because the sandstone layers show an upward increase in frequency, bed thickness and grain size. The sandstone lenses and sheets (Sp, Sh, and Ss) containing plant stems in the lower unit are likely deposits of subaqueous distributary channels and sheet sand in a delta front environment. The siltstone and silty mudstone layers (Fsl) represent the deposition of materials from interdistributary bays. The fossil-rich limestone layers $(\mathrm{Mb})$ in the middle unit are undoubtedly indicative of deposition in a shallow sea. The Gigantopteris flora-bearing coal seams (C; Figure 3a) (cf. Liu \& Sun, 2008; Li, Chen, et al., 2006) suggest that a large portion of the upper unit was deposited on a delta plain, including interdistributary bay siltstone (Fsl), distributary channel sandstone (Ss/Sp) and swamp coal seams (C). Notably, a delta front unit probably exists as a transition from the middle unit to the upper unit, but these rocks were overlooked in our field observation. This interpretation is supported by the fact that the rock layers show a rather consistent attitude and the lack of thrusts mapped in Section $\mathrm{A}-\mathrm{A}^{\prime}$.

In summary, the late Permian Raggyorcaka Formation was likely deposited in a river-dominated delta and neritic environment. 


\subsubsection{Kanglu Formation}

Description. The Kanglu Formation predominantly consists of clastic rocks (Figures $4 \mathrm{~d}-4 \mathrm{~g}$ ) that contain a substantial amount of volcanic detritus compared to that of the underlying Raggyorcaka Formation (Table S3 and Figure 8b). Generally, the formation shows a fining-upward sequence that can be divided into two minor sedimentary units. The upper unit is approximately twice as thick as the lower unit (Figure 3). In the lower unit, a >3-m-thick massive gray conglomeratic coarse-grained sandstone (Gcp) (Figure 4e) at the base is overlain by gray, moderately thick medium- to coarse-grained sandstone ( $\mathrm{Sp}$ ) and interbedded gray to purplish thick-bedded conglomeratic coarse-grained sandstone and medium- to thin-bedded coarsegrained sandstone (Gcp and Sp; Figure 4f). The upper unit fines upward from a purplish red, very thick bedded, granular to pebble conglomerate (Gcp) to a gray, medium-bedded, coarse-grained sandstone (Sp) and finally to a dark gray, medium- to thin-bedded, fine-grained sandstone (Sh/Ss) and thin siltstone (Fsl) layers (Figure 4d).

The sandstone beds contain abundant parallel bedding and some flute casts (Sh) (Figure 4g), and the conglomerate and coarse-grained sandstone beds frequently show planar and wedge cross beddings with an intersection angle of $20-40^{\circ}$ and basal scouring structures (Gcp and Sp; Figures $4 \mathrm{e}$ and $4 \mathrm{f}$ ). Mold fossils of marine bivalves and brachiopods are common within the sandstone beds (Figure 5c), particularly in the upper unit.

Facies interpretation. The fining-upward clastic deposition, current-related structures, and abundant shell fossils in the Kanglu Formation resemble that of a storm-dominated shelf environment (cf. Nichols, 2009). The conglomerate and coarse-grained sandstone with abundant cross beddings (Gcp and Sp) within the lower unit and the base of upper unit can be considered to be coastal and shoreface facies deposits based on the continuous lateral extension (over hundreds of meters). The medium- to fine-grained sandstones (Sh and Ss) of the upper unit likely represent a change into offshore transition deposits because of the enrichment of bivalve fossils and thin sheet-like beds. In addition, the abundant siltstone layers (Fsl) in the uppermost portion evidently suggest an offshore transition facies.

\subsubsection{Yingshuiquan Formation}

Description. The Yingshuiquan Formation contains more than four sedimentary cycles and can be divided into a fine-grained clastic lower unit and carbonate upper unit (Figures 3 and $4 \mathrm{~h}$ ). The lower unit contains rhythmically interbedded, gray to dark gray, thin-bedded, fine- to medium-grained sandstone (Sh and Ssw), thin siltstone (Fsl) and some oolitic and argillaceous limestone (Go and M). The upper unit consists of light gray to gray, medium-bedded oolitic limestone (Go), calcilutite and argillaceous limestone layers (Cm and $\mathrm{M}$ ), and some clastic rock layers (Sh and Ssw). The ooid grains usually display composite annular zoning and have a diameter of $\sim 1 \mathrm{~mm}$. A few oncolites are also contained in the oolite limestones, and a few medium-bedded pisolitic limestone beds appear within the upper unit (Figure $5 \mathrm{~g}$ ). Additionally, a certain amount of bioclastic fragments and intraclasts were observed in limestone beds $(\mathrm{Gb})$ of the upper unit (Figure 5f).

All the lithofacies in the Yingshuiquan Formation, especially the carbonate rocks (Gb), contain abundant fossils, such as bivalve and brachiopod molds, crinoid stems, and foraging traces (Figures 3 and 5f). Asymmetric ripple marks are commonly preserved on the bedding planes of oolitic limestone and exhibit various shapes, such as linear and curvilinear. These marks exhibit a general wavelength of $\sim 1 \mathrm{~m}$ but sometimes reach $\sim 2 \mathrm{~m}$ (Figure 4i). The sandstone occasionally exhibits swash cross-bedding structures with a small intersection angle of $<20^{\circ}$ (Ssw; Figure $4 \mathrm{j}$ ). The lithofacies in Section B-B' show no differences from those in $\mathrm{A}-\mathrm{A}^{\prime}$ except that sedimentary structures, such as swash cross bedding and parallel bedding, within either sandstone or limestone layers, appear more frequently.

Facies interpretation. The ripple mark-bearing oolitic limestones (Go) represent high-energy shoal depositions in either the platform interior or platform margin of shallow marine, while calcilutite/argillaceous limestones $(\mathrm{Cm}$ and $\mathrm{M}$ ) could be interpreted as carbonate platform interior sediments. The oolite structures including asymmetric ripple mark, planar lamination, and cross bedding, indicate an evident influence of storm or tidal currents (cf. Lehrmann et al., 2012; Nichols, 2009). The fine-grained clastic rocks (Ssw, Sh, and Fsl) are indicative lithofacies of a clastic continental shelf. In summary, a mixed continental shelf of shallow marine is presumed to be the likely sedimentary environment for the Yingshuiquan Formation. 


\subsubsection{Kangnan Formation}

Description. Although Sections A-A' and B-B' display some differences in their lithofacies for the Kangnan Formation, soft-sediment gravity-gliding structures, such as convolutions, deformed bedding and limestone nodules, are widespread within the carbonate rocks (Figures 4l-4n). The A-A' section predominantly consists of intercalated, light gray, thin-to-medium-bedded calcilutite $(\mathrm{Cm})$ and gray, thin-bedded micrite $(\mathrm{M})$ (Figure 4h). Extensive bioturbation structures, for example, biological relic structures, characterize the calcilutite layers and have largely destroyed the bedding (Figures $5 \mathrm{~h}$ and $5 \mathrm{i}$ ). In addition, the argillaceous limestone commonly features convolution and deformation bedding structures that have become competent discrete nodules (Rnb) encompassed within the rheological calcilutite matrix in certain locations (Figures $4 \mathrm{~m}$ and $4 \mathrm{n}$ ).

Two sedimentary units were determined for the $\mathrm{B}-\mathrm{B}^{\prime}$ section: including a lower greenish gray or dark gray clastic rock unit and an upper dark gray thin-bedded clast-supported nodular limestone unit. The major lithofacies of the lower part are massive clast-supported conglomerate and conglomeratic coarse-grained sandstone with reverse grading in the bottom, which changes to normal grading toward the top (Gcm; Figure 4k), medium- to coarse-grained plane-parallel laminated (Sh) and rippled sandstone (Sr) and thinlayered siliceous siltstone with horizontal lamination (Fsl). The upper unit of Section B-B' has the same lithofacies as Section A-A' (Figure 41), which is fossiliferous limestone (Rnb and $\mathrm{Cm}$ ) with gastropod and ammonite fossils.

Facies interpretation. The thin, dark carbonate layers with pervasive soft-sediment gravity-gliding structures ( $\mathrm{Rnb}$ and $\mathrm{Cm}$ ) found in Sections $\mathrm{A}-\mathrm{A}^{\prime}$ and $\mathrm{B}-\mathrm{B}^{\prime}$ are probably indicative of abyssal deposits derived from slumping of the carbonate platform that is located immediately above. The inference is also supported by intense bioturbation within the calcilutite $(\mathrm{Cm})$, which commonly implies the lack of wave and storm disturbance in deep marine environment. In Section B-B', the massive conglomeratic rocks (Gcm) represent high-density turbidity flow sediments of a dissecting current channel in an inner to middle fan environment. The sandstone (Sh and Sr) could be interpreted as low-density turbidity current flow deposit in a middle or outer fan environment (cf. Walker, 1978), Tb and Tc lithofacies of Bouma sequences according to Bouma's (1962) classification scheme, or channel-levee environment. The presence of thinly laminated siliceous siltstone (Fsl) probably indicates deposition at the most distal ends of a turbidite fan )cf. Walker, 1978).

\subsubsection{Stratigraphic Age Control Using Index Fossils}

A variety of age-indicating macrofossils, especially index fossils, were obtained from the late Permian to middle Triassic sedimentary rocks at Raggyorcaka (Figures 3, 5, and 6). The Leptodus nobilis fossils collected in the dark limestone of the middle Raggyorcaka Formation place the Formation into the Changhsingian (Figures 5d and 5e). This finding is consistent with the Palaeofusulina biozone identified in the same layers by Chen et al. (2009). This fusulinid fauna, which includes two subbiozones of Palaeofusulina minima and Palaeofusulina sinensis, resembles that reported in the Changhsingian limestone in the South China block and hence demonstrates a paleogeographic affinity with the Cathaysian Tethys (Chen et al., 2009). Two floral genera, Gigantopteris and Gigantonoclea, were found in the coal seams of the upper unit and also support the age and paleogeographic estimates (Chen et al., 2006; Liu \& Sun, 2008, and references therein).

Abundant bivalve fossils, for example, Claraia, in the fossiliferous sandstone and carbonate beds of the Kanglu and Yingshuiquan Formations, constrain their ages to the early Triassic. The Kangnan Formation is dated precisely to the Anisian Stage of the middle Triassic based on the occurrence of Philippites and Balatonites ammonite fossil assemblages (Figure 6) collected from the massive conglomeratic sandstone in the lower unit in Section B-B'. The two ammonite species Philippites cf. erasmi (Mojisovics) and Balatonites sp. nov. indet. have rarely been reported in China, and their protospecies were discovered within the western Tethys strata in the Alps.

\subsubsection{Paleocurrent Direction}

The marine paleocurrent flowing directions vary from WNW to NE in the dip direction rose diagrams (Figure 2). However, four clusters of directions, including WNW, NW, north, and NE, are quite evident (Figure 2), which indicate that the terrigenous paleocurrents generally flowed from north to south. A similar result is also indicated by the stereographic projections of the two statistical data sets from the northern and southern limbs of the Raggyorcaka syncline (Figure 7). The attitude projection of the northern limb indicates two dominant paleocurrent directions of NW and NNE, and the southern limb indicates similar directions of WNW and NE. 


\subsubsection{Summary and Regional Stratigraphic Correlation}

The interpretation of depositional environments shows that the late Permian-middle Triassic sedimentary rocks in Raggyorcaka generally display a retrograding sequence that changes from the delta and neritic facies of the Raggyorcaka Formation, to the littoral facies of the Kanglu Formation, then to the mixed continental shelf facies of the Yingshuiquan Formation, and lastly to deep marine facies of the Kangnan Formation (Table 1 and Figure 3). Another similar retrograding sequence has also been described in Juhuashan to the west of Raggyorcaka (Figure 1), which was later conformably overlain by the middle-late Triassic prograding sequence. In Juhuashan, the Ladinian-early Norian shallow marine carbonate rocks of the Juhuashan Formation conformably rest on the Anisian Kangnan Formation (Chen et al., 2009; Li, Chen, et al., 2006, 2016; Wang et al., 2007, Wang, Fu, et al., 2008) and are angularly unconformably overlain by the late Triassic Nadi Kangri Formation (Figure 3), which consists of bimodal volcanic rocks and terrestrial clastic rocks (Wang, Fu, et al., 2008; Zhang et al., 2011; Zhai, Jahn, Su, Wang, et al., 2013). Take these two intervals together, the late Permian-Triassic sediments in the Raggyorcaka and Juhuashan regions of the southern NQB generally display a complete marine transgression-regression cycle (Figure 3). The abyssal deposits of the Kangnan Formation indicate that the deepest water environment occurred in the Anisian. This marine cycle was ended by the Norian-Rhaetian bimodal volcanism and terrestrial sedimentation (Figure 3).

In the southern NQB, the Triassic deposition of a marine transgression-regression cycle was also reported at Riwanchaka in the western segment of the NQB (Li et al., 2016; Xie et al., 2018) and those in Kangrucaka and Janghgaida Rinag to the east (Wen, 1979; Zhu et al., 2005, 2010). The Olenekian conodont-bearing Yingshuiquan Formation in Riwanchaka is also characterized by the presence of carbonate platform facies, including oolitic limestone with a large quantity of irregular ooids and oncolites (up to $1 \mathrm{~cm}$; Xie et al., 2018). Moreover, a similar Induan-Ladinian marine transgressive sequence was discovered in Kangrucaka and Janghgaida Rinag (Figure 1; Wen, 1979; Zhu et al., 2005, 2010). This sequence includes Induan delta-littoral facies of the Kanglu Formation, Olenekian carbonate platform facies of the Yingshuiquan Formation, and Anisian-Ladinian continental shelf facies of the Kangnan Formation (Wen, 1979; Zhu et al., 2005). In particular, a continuous Triassic marine transgression-regression succession that could also be classified into an earlier early-middle Triassic retrograding subsequence and a subsequent late Triassic prograding subsequence is preserved in Janghgaida Rinag (Figures 1 and 3; Chen et al., 2009; Zhu et al., 2005, 2010). Norian-Rhaetian bimodal volcanic rocks and terrestrial clastic rocks that angularly unconformably overlie the Triassic sequence have also been found to the north, such as in Woruo and Nadi Kangri (Fu et al., 2010; Wang et al., 2007, Wang, Fu, et al., 2008).

However, two distinct variations are used to discriminate the Janghgaida Rinag Triassic sequence from the Raggyorcaka one. First, the deepest water environment of the former was a shallow sea, which was much shallower than deep marine environment in the latter (Figure 3). Second, the Janghgaida Rinag sequence indicates a detrital source generally from the south (SE, SES, and SWS; Zhu et al., 2005, 2010).

\subsection{Sedimentary Provenance}

\subsubsection{Sandstone Petrological Analyses}

When all the sandstone modal analysis data sets are plotted in five ternary diagrams (Dickinson et al., 1983; Dickinson \& Suczek, 1979), a prominent provenance transition beginning in the late Changhsingian of the Permian (upper Raggyorcaka Fm.) is clearly demonstrated from quartzose types, including the craton interior and recycled orogen, to a quartz-poor magmatic arc province (Figure 8). This interpretation is corroborated by upward increase of volcanic/plutonic debris input in the upper Raggyorcaka Formation (Figure 8b) and by the dominant youngest detrital zircon population (236-288 Ma; Figures S2 and S3). Among the six sandstone samples from the upper Raggyorcaka Formation, four exhibit a volcanic debris proportion of $>16 \%$, much higher than that of $<2 \%$ for the 15 samples from the lower unit (Figure $8 \mathrm{~b}$ and Table S3). Volcanic rocks fragments prevail in the 30 specimens from the Kanglu, Yingshuiquan, and Kangnan Formations and range from $12 \%$ to $69 \%$ in 28 of 30 samples and exceed $30 \%$ in 15 samples (Figure $8 \mathrm{~b}$ and Table S3).

The Raggyorcaka Formation samples are predominantly feldspathic or lithic quartz sandstone, and samples from the other formations are composed of litharenite, arkose, and their transitions (Figure 8a). On the QFL diagram, the lower Raggyorcaka samples mainly plot in the craton interior field, and almost all of the samples 
plot in the recycled orogen field in the QmFLt diagram (Figures 8c and 8e) as a result of the shifting of Qp from the $\mathrm{Q}$ pole to Lt pole. Both cases indicate a predominant craton-derived sand source either from the exposed shield in the craton or from rifted continental margin with multicyclic sand for lower Raggyorcaka Formation (cf. Dickinson et al., 1983; Dickinson \& Suczek, 1979). In contrast, the sandstone samples from the Kanglu, Yingshuiquan, and Kangnan Formations are strongly characterized by a magmatic arc provenance. On the QmFLt diagram, most of these sandstones show an arc origin source, particularly a transitional arc setting with abundant plutonic monocrystalline debris (Figure 8e), which is consistent with the corresponding trend on the QpLvLs and QmPK diagrams (Figures 8d and 8f). However, as many as half of the samples fall in the basement uplift and the recycled orogen fields (Figure 8c).

\subsubsection{Interpretation}

Because constant neritic carbonate deposition was the dominant form of sedimentation in the Carboniferous to Permian along the southern margin of the NQB (Figure S4; Li, Huang, et al., 2006; 2016), chert nodules or lamellae within the carbonate probably contributed to the appreciable Qp content within the clastic sediments of the lower Raggyorcaka Formation as shown by the content of sedimentary lithic fragments (Ls; Table S3). Therefore, a stable craton province rather than collisional orogen or foreland is likely one of the major provenance sources for the lower Raggyorcaka Formation. Moreover, for the outboard plots of early-middle Triassic sandstone in the QFL diagram, the probability of an uplifted basement origin is very low because only a few older ( $>450 \mathrm{Ma}$ ) detrital zircon ages could be detected, which are similar to that of the NQB crystalline basement (cf. Peng et al., 2011; Liu et al., 2013; Zheng et al., 2015; Figures S2 and S3). Outliers within the recycled orogen province, specifically the collisional orogen or foreland uplift, would also be precluded according to the finding that a marine transgression event characterizes the early-middle Triassic succession (Figures 3-5).

\subsubsection{Detrital Zircon MDAs and Provenance}

Almost all the zircon grains are characterized by an igneous origin with Th/U ratios of $>0.1$ (Table S4), which is consistent with the magmatic oscillatory zoning seen in the cathodoluminescence images (Figure S1). Generally, the samples have a concentrated youngest age group of 236-288 Ma with a continuous sequence of YC1- $\sigma(3+)$ /concordia intercept age (Figures 9a, S2, and S3 and Table 2). The corresponding zircon grains have largely retained their euhedral morphology and feature narrow oscillatory zoning (Figure S1), which likely implies an origin from intermediate to acidic igneous rocks.

Two of the Raggyorcaka Formation samples, 20110626D3-RZ and 14054-RZ1, which were collected from the lower and upper units, respectively, yielded similar populations of U-Pb detrital zircon ages (Figure S2). Sample 20110626D3-RZ $(n=85)$ presents three prominent age peaks at 236-288 (with subpeaks at $\sim 251.6$ and $\sim 280 \mathrm{Ma}$ ), 472.2, and $\sim 960 \mathrm{Ma}$, as well as other minor clusters at 500-600, 650-800, 1,857, 2,3502800, and 3,000-3,300 Ma (Figure S2). Moreover, four WMAs of 247.1 \pm 3.9, $279.6 \pm 2.6,472.2 \pm 4.0$, and $960.9 \pm 5.7 \mathrm{Ma}$, which almost equal to the peak values, were obtained (Figure S2). Sample 14054-RZ1 ( $n=50$ ) presents two notable age peaks at $\sim 255.8$ Ma within the span of 236-288 and 997 Ma within the span of 900-1,200 Ma and scattered clusters at 300-400, 400-500 (concentrated), 500-900, 1,300-2,000, 2,500, and 3,500-3,600 Ma (Figure S2). The 20110626D3-RZ and 14054-RZ1 samples yield YC2- $\sigma(3+)$ MDAs of $250.7 \pm 2.2$ and $254.5 \pm 9.2$, respectively, which represent slight deviations from their stratigraphic ages (Wuchipingian and Changhsingian, respectively; Figure 3).

The two samples from the Kanglu Formation show age distributions similar to those of the Raggyorcaka Formation samples but with a more striking youngest group of 236-288 Ma, which includes two peak ages of $\sim 248.6$ and $\sim 258.3$, for samples PM034-7-RZ $(n=47)$ and 14056-RZ1 $(n=90)$ from the middle and top, respectively (Figure S2). A very good YC2- $\sigma(3+)$ MDA of $249.1 \pm 1.0 \mathrm{Ma}(n=39, \mathrm{MSWD}=0.54)$ was obtained for PM034-7-RZ, and a good YC2- $\sigma(3+)$ MDA of 250.2 \pm 2.0 Ma was obtained for 14056-RZ1. Additionally, the latter yields four consecutive WMAs (YC1- $\sigma(2+)$ MDAs) of $244.3 \pm 3.4,251.8 \pm 2.8,259.3 \pm 2.0$, and $268.2 \pm 3.0 \mathrm{Ma}$ (Figure S2). According to the stratigraphic context, the above two YC2- $\sigma(3+)$ MDAs indicate robust candidates for the TDA of the Kanglu Formation (very likely Induan-Olenekian).

Samples 1610-b1 from the Yingshuiquan Formation and 1611-b1 from the Kangnan Formation exhibit a similar youngest detrital zircon group (230-288 Ma) with a successive WMA (YC1- $\sigma(2+)$ MDA) sequence. This group is far more pronounced than the other weak age clusters in the age-probability diagram (Figure S3). Sample 1610-b1 $(n=41)$ produces three peak values of $\sim 252, \sim 262.6$, and $\sim 276.7$ Ma and a $\mathrm{YC} 2-\sigma(3+) \mathrm{MDA}$ of $248.6 \pm 3.0$, which corresponds to its stratigraphic age (middle-late or late Olenekian) 


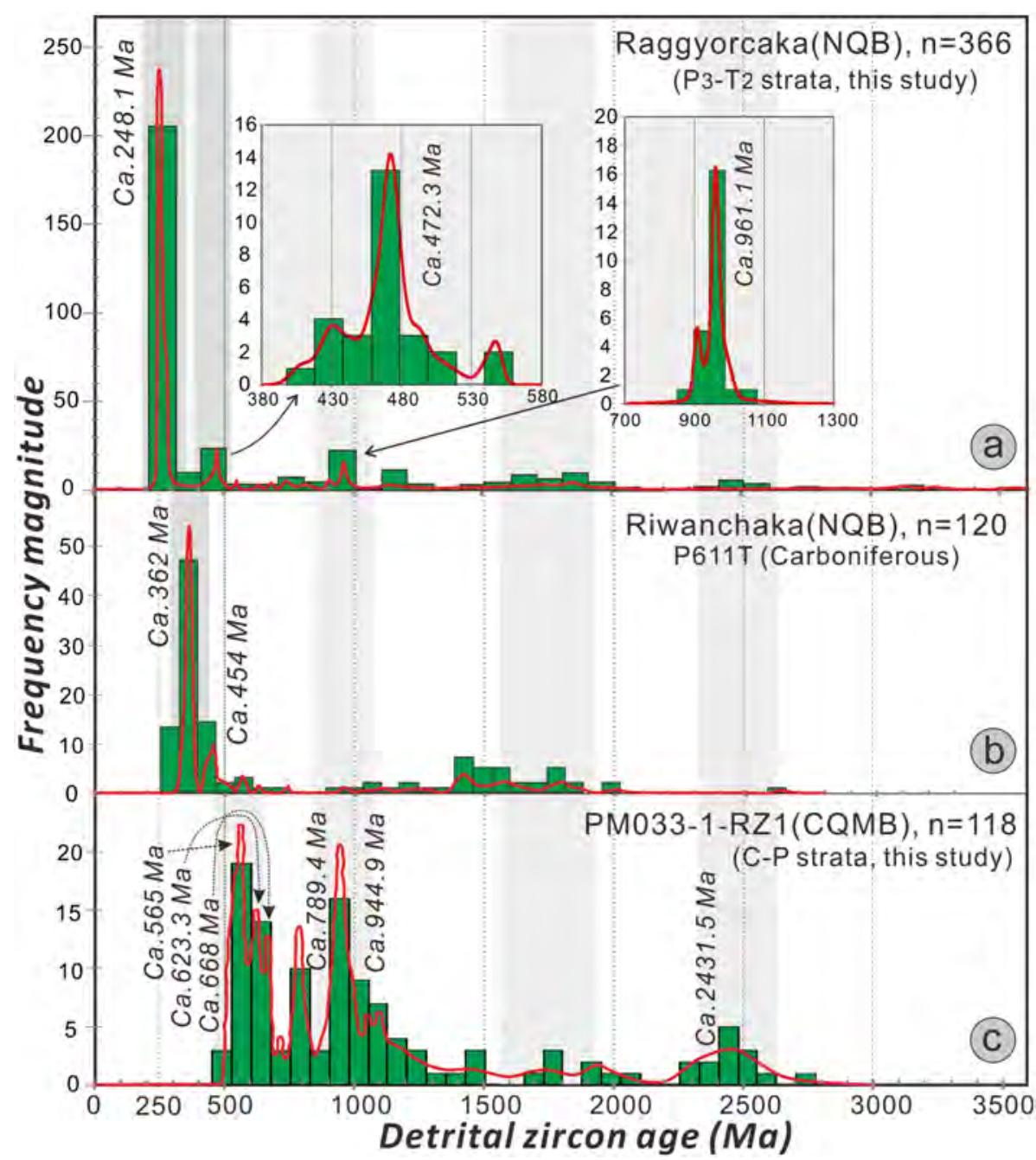

Figure 9. Detrital zircon age-frequency diagrams of sandstone samples from the NQB and CQMB. (a) Sum of detrital zircon ages from all six Raggyorcaka samples (NQB). (b) Riwanchaka sandstone sample P611T from the NQB (Li et al., 2016; Peng et al., 2014). (c) Sample PM033-1-RZ1 from the CQMB. NQB = North Qiangtang block; CQMB = Central Qiangtang metamorphic belt.

as evidenced by the stratigraphic context (Figure 3). Sample 1611-b1 $(n=41)$ yields a peak age of $\sim 256 \mathrm{Ma}$ and a YC2- $\sigma(3+)$ MDA of $244.2 \pm 2.3 \mathrm{Ma}$ (Figure S3), and the latter is generally consistent with the stratigraphic age (Anisian) indicated by the ammonite fauna on the same stratigraphic horizon (Figure 3).

The composite age spectrum of the six samples is generally characterized by a high-probability peak age of $\sim 248.1 \mathrm{Ma}$, two moderate peak ages of $\sim 472.3$ and $\sim 961.1 \mathrm{Ma}$, and sporadic clusters, such as at 700-800, 1,000-1,300, 1,500-2,000, 2,500, and 3,000-3,300 Ma (Figure 9a). The late Paleozoic quartz sandstone sample of Mayer Kangri yields a distinct age distribution $(n=118)$ with populations much older than the TDA, including peaks of $~ 565,623.3,668,789.4,944.9$, and 2431.5 Ma (Figure 9c).

\subsubsection{Hf Isotopes for the Youngest Detrital Zircons Group}

The 28 detrital zircon grains with ages of 236-288 Ma from sample 14056 exhibit low ${ }^{176} \mathrm{Hf} /{ }^{177} \mathrm{Hf}$ ratios and $\varepsilon_{\mathrm{Hf}}(t)$ values generally between -25.3 and -9 , and only one sample has a $\varepsilon_{\mathrm{Hf}}(t)$ value of -0.2 (Table S5 and Figure $11 \mathrm{~b})$. In the $\varepsilon_{\mathrm{Hf}}(t)$ - $t$ diagram, these grains predominantly appear in the field between the lower and upper crust (Figure 11b). Furthermore, they all display large Hf model ages $\left(T_{\mathrm{DM}}\right)$ in the range of 936-1926 Ma, with an average of 1,528 Ma, and considerably older Hf crustal model ages $\left(T_{\mathrm{DM}}^{\mathrm{C}}\right)$ ranging from 1,311 to $2,887 \mathrm{Ma}$, with an average of $2268 \mathrm{Ma}$ (Table S5). These features, including the negative $\varepsilon_{\mathrm{Hf}}(t)$ values and the $T_{\mathrm{DM}}$ and $T_{\mathrm{DM}}^{\mathrm{C}}$ ages that are far older than the crystallization ages of 236-288 Ma, indicate a crustalmelting origin for the source magmatism. 


\section{Discussion}

\subsection{Implications for the Origin of the NQB}

Determining the northernmost boundary of the peri-Gondwana continental realm is an increasingly compelling geological issue (Fan et al., 2015; Gehrels et al., 2011; Kapp et al., 2003; Li, 1987; Li, Zhai, Dong, et al., 2006, Li, Zhai, Chen, et al., 2006, Li, Chen, et al., 2006, Li, Huang, et al., 2006; Pullen et al., 2008, 2011; Song et al., 2015, 2017; Yin \& Harrison, 2000; Y. C. Zhang, Shen, et al., 2012). The provenance of the CQMB has been verified to be predominantly from Gondwana to the south (Kapp et al., 2003; Pullen et al., 2008, 2011), including the Paleozoic passive continental margin of the SQB and Paleo-Tethys Ocean (Li, Chen, et al., 2006, Li, Huang, et al., 2006, 2016; Liang et al., 2012; Li et al., 2019; Zhao et al., 2014). The tectonic origin of the NQB, however, is still widely debated, that is, either from Gondwana or Cathaysian/Laurasian (Li, Chen, et al., 2006, Li, Huang, et al, 2006, 2016; Pullen et al., 2011; Pullen \& Kapp, 2014; Song et al., 2015, 2017).

The detrital zircon age spectra are widely considered as a reliable proxy for assigning tectonic origins (Gehrels et al., 2011). In general, age distributions in the range of $>500 \mathrm{Ma}$ are observed within the NQB samples, including two peak values at 940-1,000 and 2,400-2,600 Ma and groups within the ranges of 500-900 and 1,400-2,000 Ma (Figures 9a, 9b, and 10a). These features closely resemble those of the sandstone samples collected from both the CQMB (Figure 9c and 10b; Dong et al., 2011; Fan et al., 2015; Kapp et al., 2003; Pullen et al., 2008; Zhao et al., 2014) and the Tethyan Himalaya (Figure 10c; Gehrels et al., 2011; cf. Zhu et al., 2011, 2013). However, three notable peaks at 472.3, 362, and 248.1 Ma occur only in the NQB (Figures 9a and 9b), while prominent summits in the range of 500-900 Ma, such as 565, 623, 668, and $789 \mathrm{Ma}$, are observed from the samples of the CQMB (Figure 9c). The age peak of $565 \mathrm{Ma}$ for the sample from the CQMB (Figure 9c) is typical of the Pan-African orogeny (570-520 Ma; Li et al., 2008). The early Ordovician age group has also been found within Carboniferous and Permian sandstone samples from the NQB (Gehrels et al., 2011; Peng et al., 2014), which also show minor peaks or clusters of PanAfrican ages (Figure 9b). Nonetheless, examples of Cambrian-Ordovician tectonic events are widespread in the CQMB and NQB, including basement metamorphism, for example, the 502- to 471-Ma Duguer orthogneiss (Liu et al., 2016; Pullen et al., 2011), 486- to 480-Ma Bensong Co granitic gneiss (Hu et al., 2015), and 463.7-Ma Ejiumai gneiss (Zheng et al., 2015).

Based on these observations, the NQB and CQMB are generally undistinguishable from the zircon age populations of $>400 \mathrm{Ma}$ (Figure 10). However, similar characteristics are also identified in the Paleozoic samples of the Cathaysia block (Figure 10d; cf. Wang et al., 2010; Li et al., 2012). In fact, a consensus has been reached that these blocks gradually drifted northward from Gondwana after the Cambrian (cf. Gehrels et al., 2011; Metcalfe, 2013). Recently obtained paleomagnetism results for the early Permian and late Triassic lavas in the NQB (Song et al., 2015, 2017) clearly indicate the Gondwana-affinity for the NQB, which was also reported by Zhu et al. (2011, 2013) and Gehrels et al. (2011). Moreover, the widespread Carboniferous-late Permian warm-water fauna in the southern NQB (Chen et al., 2006, 2009; Liu \& Sun, 2008; Li et al., 2016; Wu et al., 2009; Zhang et al., 2015), which are different from the Carboniferous-early Permian cold-water fauna and diamictite in the CQMB and SQB (Liang et al., 1983; Li, 1987; Li et al., 1995; Li, Chen, et al., 2006, Li, Huang, et al., 2006), indicate that the NQB rifted away from Gondwana probably in the early Paleozoic and became adjacent to the peri-Cathaysian blocks no later than the Carboniferous (Figure 12c) because of the late Devonian-early Carboniferous arc-type magmatism in the southern NQB.

\subsection{Carboniferous-Triassic Sedimentary Evolution of the Southern NQB}

A stable shallow sea environment remained in the southern NQB from the Carboniferous to the middle Permian as indicated by the presence of a large suite of carbonate platform limestones with warm-water faunas (Figure S4). Then a rather complete marine transgression-regression cycle developed in the late Permian-Triassic (Figure 3). At the bottom of the sequence, the early Carboniferous Riwanchaka Formation conformably overlies the late Devonian-early Carboniferous (374-346 Ma) volcanic rocks of the Wangguoshan Formation (Figures S4 and 10b) (Li et al., 2016; Peng et al., 2014). The Riwanchaka formation was largely sourced from the Wangguoshan volcanic rocks based on a youngest detrital zircon group of 400-325 Ma (peaks at $\sim 362 \mathrm{Ma}$ ) and similar $\varepsilon_{\mathrm{Hf}}(t)$ values (Figures 9b and 11; Peng et al., 2014; Li et al., 2016). 


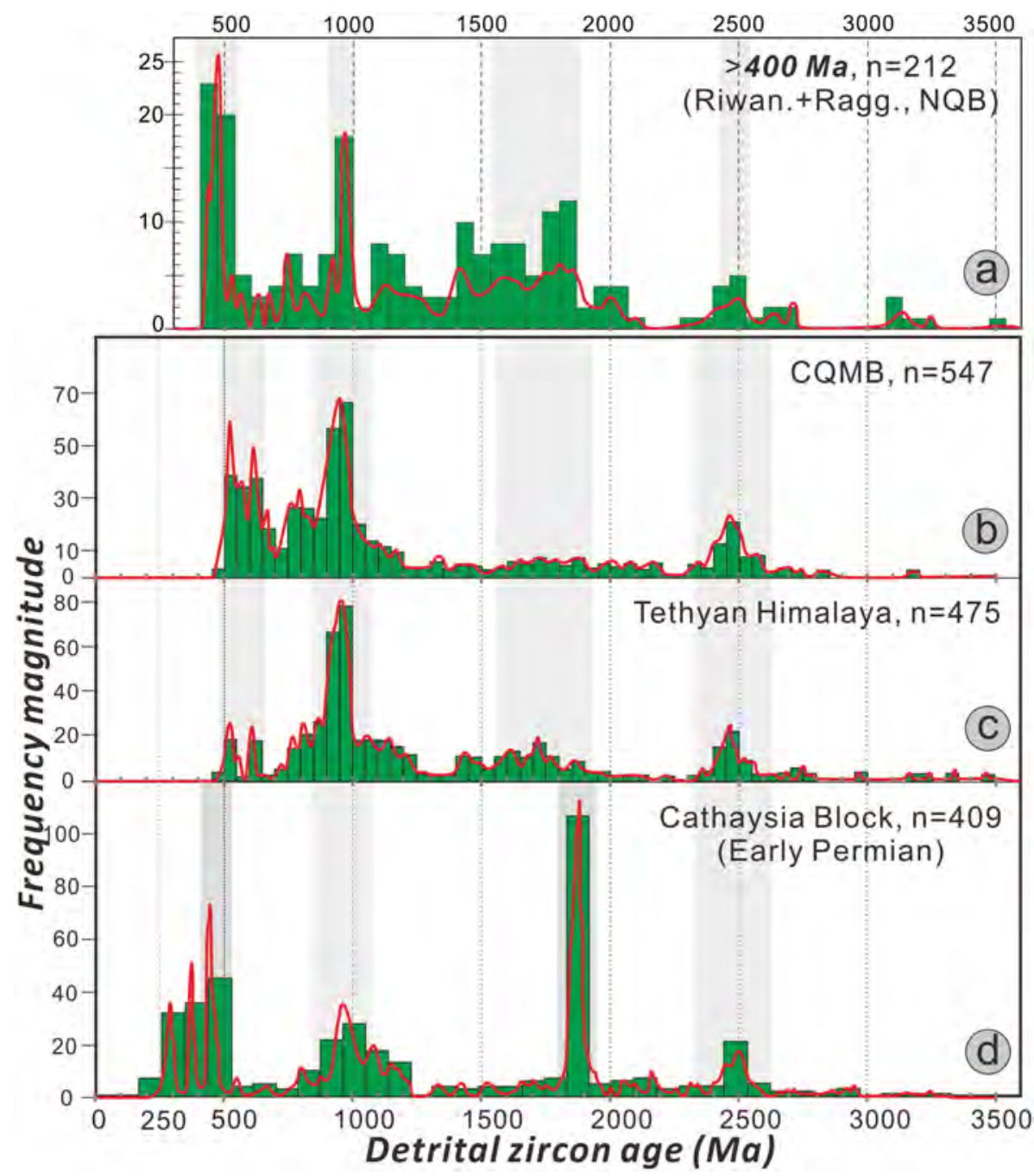

Figure 10. Detrital zircon age-frequency diagrams of the blocks of the Tibetan plateau and Cathysian continent. (a)The $>500$-Ma age spectra of the Riwanchaka and Raggyorcaka samples. (b, c) Sandstone samples from the CQMB (Dong et al., 2011; Kapp et al., 2003; Pullen et al., 2008; Zhu et al., 2011) and the Tethyan Himalaya (Zhu et al., 2011, 2013). (d) Paleozoic sandstone samples from the Cathysia (cf. Li et al., 2012; Wang et al., 2010).

The late Permian-middle Triassic retrograding subsequence is widely preserved in the southern NQB, including at Raggyorcaka, Kangrucaka, and Janghgaida Rinag (Figure 1). Notably, the middle Triassic sediments in Janghgaida Rinag indicate mixed continental shelf facies, which are shallower than deep marine facies at Raggyorcaka (Figure 3) and likely show a lateral variation in the sedimentary environment across the same basin. The subsequent Ladinian-early Norian prograding subsequence is also widespread in the southern NQB and rests conformably on the earlier subsequence, such as in Juhuashan to the west (Chen et al., 2009; Li, Chen, et al., 2006, 2016; Wang et al., 2007, Wang, Fu, et al., 2008) and Janghgaida Rinag to the east of Raggyorcaka (Zhu et al., 2005, 2010; Chen et al., 2009). However, the Janghgaida Rinag Carnian-Norian neritic-delta deposits have been shown to display a different sedimentary provenance generally to the south (probably the CQMB; Zhu et al., 2005, 2010). We therefore infer that Janghgaida Rinag was situated on the southern side of the basin, as opposed to the earlier retrograding subsequence at Raggyorcaka. Finally, Norian-Rhaetian bimodal volcanic rocks (223-202 Ma) and terrestrial sediments (Nadi Kangri Formation) unconformably overlies the late Permian-early Norian marine sediments in the southern NQB (Fu et al., 2010; Wang et al., 2007, Wang, Fu, et al., 2008; Zhai, Jahn, Su, Wang, et al., 2013; Zhang et al., 2011; Figure 3).

The Raggyorcaka detrital zircon grains, which show a concentrated youngest age population of 236-288 Ma and a conspicuous peak of 248.1 Ma (Figures S1, 9a, and 11a and Table S4), evidently show an origin from 

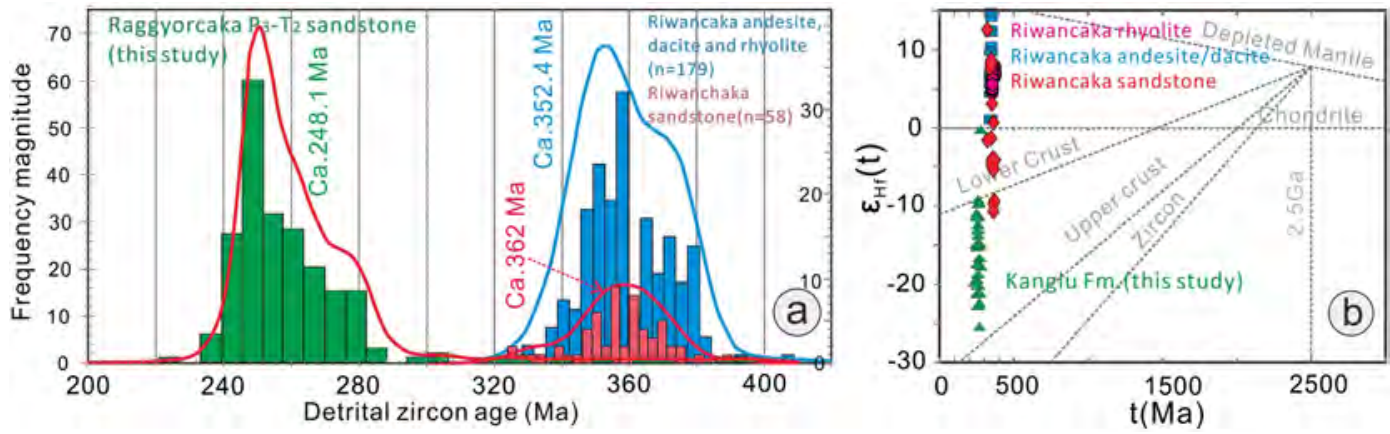

Figure 11. (a) A compilation of detrital zircon age distributions ( $<400 \mathrm{Ma}$ ) from Raggyorcaka sandstone samples, an early Carboniferous Riwanchaka sandstone (Li et al., 2016; Peng et al., 2014) and arc-related volcanic rocks in Riwanchaka and Laxiongco to the west (Jiang et al., 2015; Wang et al., 2017). (b) Zircon $\varepsilon_{\mathrm{Hf}}(t)$ values of the youngest detrital zircons (236-288 Ma) from the Raggyorcaka sandstones (this study), detrital zircons of <400 Ma from the Riwanchaka sandstone (Li et al., 2016; Peng et al., 2014), and volcanic rock zircons (374-346 Ma) from Riwanchaka and Laxiongco (Jiang et al., 2015; Wang et al., 2017).

intermediate to acidic igneous rocks (Figure S1 and Table S4). These observations are consistent with the previous studies, such as 263-280 Ma for four sandstone samples from the early Triassic Yingshuiquan Formation in the western segment of the NQB (Xie et al., 2018) and 240-330 Ma for three Triassic sandstones collected by Gehrels et al. (2011) near Raggyorcaka. Furthermore, the MDAs calculated for each formation indicates a generally decreasing age sequence, although an outlier of $254.5 \mathrm{Ma}$ is observed for the sample 14054-RZ1 (Table 2 and Figures S1 and S2). The results are consistent with the index fossil ages (Figure 3). Combined with the sandstone petrological results (Figure 8 and Table S3) and the deduced southward flowing direction of the terrestrial paleocurrent (Figures 2 and 7 and Table S2), intense coeval plutonic activity likely occurred nearby to the north as the major clastic source for the late Permian-middle Triassic Raggyorcaka deposits in the NQB.

Given the tectonic setting in which a Permo-Triassic oceanic subduction occurred at either the northern or southern margin of the NQB, we further infer that the Permo-Triassic Raggyorcaka sequence was most likely deposited in an active continental margin, which was either a forearc basin or backarc basin. The birth of the basin, however, probably occurred much earlier at $288 \mathrm{Ma}$ (early Artinskian in the early Permian) or even in the late Devonian-Carboniferous because the recently discovered Wangguoshan Formation in Riwanchaka and Laxiongco (Figures 1 and 3) presents a very probable continental arc origin (Jiang et al., 2015; Wang et al., 2017).

\subsection{Tectonic Background and Implications for the Genesis of the CQMB}

As previously described, the two major tectonic models are inconsistent regarding the occurrence of a Paleozoic-Triassic Longmu Co-Shuanghu Tethys Ocean within the interior of the Qiangtang block between the NQB and SQB (Li, 1987; Li et al., 1995; Li, Zhai, Dong, et al., 2006, Li, Zhai, Chen, et al., 2006, Li, Chen, et al., 2006, Li, Huang, et al., 2006, 2016; Kapp et al., 2000, 2003; Pullen et al., 2008, 2011; Pullen \& Kapp, 2014; Yin \& Harrison, 2000). In the following, we test these two models and determine the tectonic origin of the basin based on our new sedimentary results and other reported geological evidence.

As we taking the allochthonous complex model into consideration (Ding et al., 2013; Gehrels et al., 2011; Kapp et al., 2000, 2003; Pullen et al., 2008, 2011; Pullen \& Kapp, 2014; Yin \& Harrison, 2000), we must note that the Permo-Triassic southward subduction of the Paleo-Tethys Ocean along the Jinsha suture could have induced a mantle-crustal interaction beneath the NQB, which leads to the ensuing arc magmatism. Considering the late Mesozoic-Cenozoic episodic large-scale crustal shortening within the NQB, that is, $\sim 185 \mathrm{~km}$ of shortening during 52->23 Ma (cf. Li, Chen, et al., 2006 and references therein), the previous $\mathrm{N}-\mathrm{S}$ distance between Raggyorcaka and the Jinsha suture was likely much larger than the present one of $\sim 170 \mathrm{~km}$. The flat-slab subduction mode, which was used to interpret the exhumation of the CQMB within a presumed single Qiantang block (Kapp et al., 2000, 2003; Pullen et al., 2008, 2011; Pullen \& Kapp, 2014), could therefore be a reasonable solution for the genesis of arc-related magmatism. However, this hypothesis seems questionable based on the details of the late Paleozoic-middle Triassic geological evolution of the southern NQB. At first, the southward subduction of the Paleo-Tethys Ocean was thought to have occurred during the middle Triassic (Kapp et al., 2000, 2003; Pullen et al., 2008, 2011) or as earlier as the Permian 

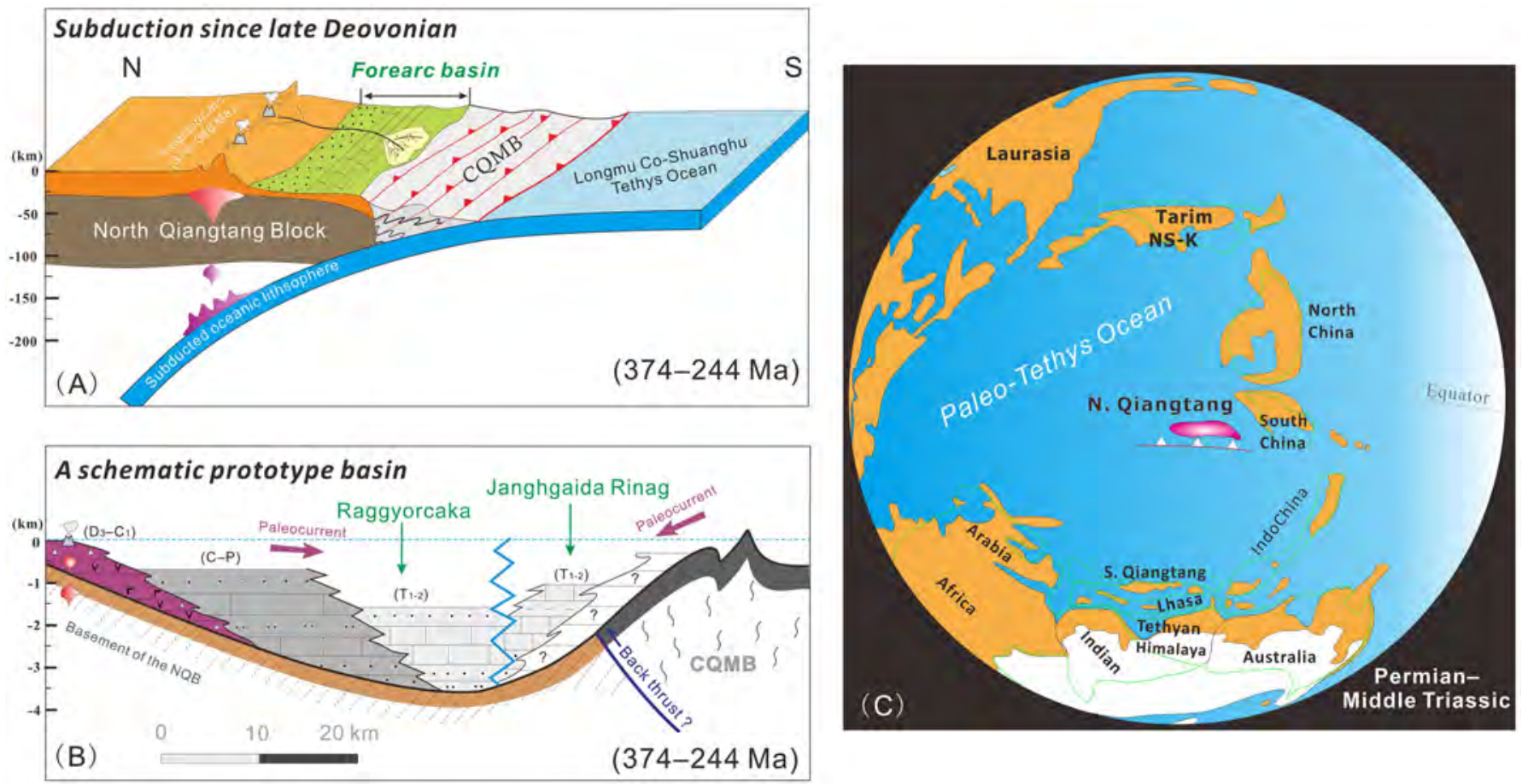

Figure 12. Schematic cartoons showing the sedimentary evolution of the late Paleozoic-Triassic forearc basin in the southern NQB and their tectonic correlation with the Longmu Co-Shuanghu Tethys Ocean. (a) A N-S trending transverse section showing the tectonic framework of the forearc basin. (b) A schematic prototype basin showing the sedimentary process. (c) A paleogeographic map showing the schematic evolution of the North Qiangtang block and the Paleo-Tethys Ocean in the Permian-Middle Triassic. Dimensions of the blocks follow the results presented by Gehrels et al. (2011), Song et al. (2017), and references therein. NQB = North Qiangtang block; CQMB = Central Qiangtang metamorphic belt.

(Ding et al., 2013), which obviously occurred after the formation of the Wangguoshan volcanics (374$346 \mathrm{Ma}$ ) and may have been coeval with the beginning of the speculated volcanism in Raggyorcaka $(\geq 288 \mathrm{Ma})$. Second, the flat-slab subduction has been shown to be a geodynamic driver for the weakening and/or cessation of the arc magmatism as shown in the Cretaceous-Cenozoic Cordillera orogens, for example, the Laramide of western North America (Liu et al., 2005, 2011, and references therein) and the western coast of South America (Manea et al., 2012; O'Driscoll et al., 2012; Ramos \& Folguera, 2009). In contrast, the southern NQB generally shows continuous magmatism over a period of $\sim 50$ Ma starting in the early Permian ( 288 Ma; Figures 9a and 11a).

On the other hand, the in situ suture model with northward oceanic subduction under the NQB (Li et al., 1995, Li, Chen, et al., 2006, Li, Huang, et al., 2006, 2016; Zhai, Zhang, et al., 2011, Zhai, Jahn, et al., 2011; Liang et al., 2017, 2012; Li et al., 2019; Wang et al., 2018) could potentially better explain the late Devonian-middle Triassic geological evolution in the southern NQB (Figure 12), primarily based on the following evidence. First, the Longmu Co-Shuanghu Tethys Ocean, which once separated the NQB and SQB (Li, 1987; Li et al., 1995), was demonstrated to be a diachronous ocean as supported by the continuous Cambrian-early Triassic (501-242 Ma) ophiolite suites (Fan et al., 2017; Hu et al., 2014; Li et al., 1995, Li, Chen, et al., 2006, Li, Huang, et al., 2006, 2016; Wang, Pan, et al., 2008; Wu et al., 2010; Zhai, Jahn, Wang, et al., 2013, 2016; Zhang et al., 2017; Zhu et al., 2006). Second, obvious biota and paleogeography differences have been recently verified across the NQB and the CQMB/SQB. The once-reported stratigraphy/biota zonation across the Qiangtang block, namely, the SQB Carboniferous cold-water fauna and glaciomarine diamictite of Gondwana affinity (Liang et al., 1983; Li et al., 1987; Liu et al., 2002; Li et al., 1997, Li, Chen, et al., 2006, Li, Huang, et al., 2006, 2016 and references therein; Fan et al., 2015) and the NQB late Permian warm-water biota of Cathaysian affinity ( $\mathrm{Li}$ et al., 1997, Li, Chen, et al., 2006Li, Huang, et al., 2006, 2016; Liu \& Sun, 2008 and references therein; Chen et al., 2009; Fan et al., 2015; Zhang et al., 2015), is extremely unlikely to correspond to the same stratigraphic horizons suggested by the allochthonous model (Pullen et al., 2011; Pullen \& Kapp, 2014). Nonetheless, the newly found Carboniferous warm-water fauna-bearing carbonate sediments (early Carboniferous Riwanchaka 
formaiton and late Carboniferous Walongshan Formation) in the southern NQB (Figure S4) provide robust evidence for the paleogeographic zonation proposed in the in situ suture model (Li, Chen, et al., 2006Li, Huang, et al., 2006, 2016 and references therein; Peng et al., 2014; Wu et al., 2009).

Based on the above results, we propose a hypothetical perspective that the Carboniferous-Triassic deposits in the southern NQB are comparable to deposits common to forearc basins worldwide (cf. Dickinson \& Seely, 1979; Noda et al., 2016). First, as described above, the late Paleozoic-Triassic tectonic framework in Central Qiangtang was likely constructed by northward subduction of the Longmu Co-Shuanghu Tethys Ocean, which means that the coeval sediments in southern NQB developed between a continental magmatic arc and an accretionary wedge (the CQMB; Figure 12). In fact, this trinity configuration is widely accepted as a first-order tectonic response to oceanic subduction along convergent margins (Dickinson \& Seely, 1979; Li et al., 2014; Maravelis et al., 2016). Forearc basins commonly occur as sedimentary depressions between the arc massif and the structural high of the accretionary complex (Dickinson \& Seely, 1979) and usually experience subsidence, which results in the accommodation necessary for sediment accumulation (Noda, 2016). The Early Carboniferous carbonate and clastic layers of the Riwanchaka Formation could be considered as the earliest sediments within the forearc basin because they overlie the arc-derived volcanics of the Wangguoshan Formation (Figure S4). Additionally, the Ordovician basement gneiss ( 463.7 Ma) has been shown to border the southern flank of the Raggyorcaka sequence (Figure 2; Liu et al., 2013; Zheng et al., 2015). These observations indicate that a large portion of the basin likely formed on the arc terrane and/or the continental crust of the NQB (Figure 12b).

Second, the sedimentary process of the late Permian-Triassic sequence resembles that of a conventional forearc basin in two main aspects: the two-sided provenance (Maravelis et al., 2016) and the shoaling-up trend in the final stage (Orme et al., 2015, 2016; Maravelis et al., 2016). The Raggyorcaka region was probably situated on the northern (inboard) margin of the basin and had a generally southward flowing terrestrial paleocurrent and a volcanic arc-dominated clastic source, while the Janghgaida Rinig region was located on the southern (outboard) margin and had a northward flowing directions and a detrital source from the CQMB to the south (Figure 12b). The marine regression event is notably shown by the widespread Ladinian-early Norian prograding subsequence in the southern NQB (Chen et al., 2009; Li, Chen, et al., 2006, 2016; Wang et al., 2007, Wang, Fu, et al., 2008) and Janghgaida Rinag (Chen et al., 2009; Zhu et al., 2005, 2010).

\section{Conclusions}

1. A complete marine transgression-regression sequence with two-sided provenance characterizes the late Permian-Triassic sediments in the southern NQB. The Raggyorcaka transgressive subsequence shows a prominent provenance shift to an active volcanic arc source beginning in the Changhsingian.

Acknowledgments

Our field work was supported by the Young Scientist Fund of the National Natural Science Foundation of China (Grant 41402177). The experimental items were financially supported by the China Geological Survey (CGS):

"1:50,000 regional geological surveys in the Gangmari area of Tibet" (Grant 1212011086062) and the Ministry of Education of the People's Republic of China (Grant 649199111027). Many thanks to Shaofeng Liu and Devon A. Orme for constructive reviews on the original manuscript. We greatly appreciate the helpful suggestions from Alex Pullen, Lin Li, and Majie Fan. All data are provided in the present manuscript and supporting information. The latter includes Text S1, Figures S1-S4, and Tables S1-S5, which are also available online (https://data.mendeley. com/datasets/z78gpghrzp/1 [https:// doi.org/10.17632/z78gpghrzp.1]).
2. The in situ suture model provides the best interpretation of the origin of the CQMB. The CarboniferousTriassic succession of the southern NQB was likely deposited in a forearc basin setting.

3. The detrital zircon age distribution of $>400 \mathrm{Ma}$ for the southern NQB and other geological evidence suggests that the NQB probably drifted from the Gondwana supercontinent in the early Paleozoic.

\section{References}

Allmendinger, R. W., Cardozo, N. C., \& Fisher, D. (2012). Structural geology algorithms: Vectors and tensors, (p. 289). Cambridge, England: Cambridge University Press.

Bouma, A. H. (1962). Sedimentology of some flysch deposits, (p. 168). Amsterdam: Elsevier.

Chen, S. M., Cheng, L. R., Wu, S. Z., \& Zhu, Y. S. (2009). Late Permian fusulinds from the Raggyorcaka Formation, northern Qiangtang, Tibet, China [in Chinese with English abstract]. Geological Bulletin of China, 28, 1725-1729.

Chen, S. M., Cheng, L. R., \& Zhang, Y. C. (2006). Restudy on the late Permian strata in northern Qiangtang area, Tibet [in Chinese with English abstract]. Journal of Jilin University (Earth Science Edition), 36, 1-4.

Cheng, L. R., Chen, S. M., Zhang, Y. C., \& Wu, S. Z. (2006). Discovery of carboniferous strata in northern Qiangtang basin, Tibet. Earth Science Frontiers, 13(4), 240-243.

Decelles, P. G., Graym, B., Ridgway, K. D., Coler, B., Srivastav, P. A., Pequera, N., \& Pivnik, D. A. (1991). Kinematic history of foreland uplift determined from Paleocene synorogenic conglomerate, Beartooth Range, Wyoming and Montana. Geological Society of America, 103, 1458-1475.

Decelles, P. G., Kapp, P., Ding, L., \& Gehrels, G. E. (2007). Late Cretaceous to middle Tertiary basin evolution in the central Tibetan Plateau: Changing environments in response to tectonic partitioning, aridification, and regional elevation gain. GSA Bulletin, 119, 654-680. 
Deng, W. M., Yin, J. X., \& Yu, Z. P. (1996). The study of basic, ultra basic and volcanic rocks in Chabu-Shuanghu areas of Qiangtang. Science in China (Series D), 26, 299-301.

Deng, X. G., Ding, L., Liu, X. H., Zhou, Y., Yin, A., Kapp, P. A., et al. (2000). The Ar-Ar geochronology of Gangma Ri blueschist in central Qiangtang of Tibet Plateau. Science Bulletin, 45(21), 2322-2326.

Dickinson, W. R. (1985). Interpreting provenance relation from detrital modes of sandstones. In G. G. Zuffa (Ed.), Provenance of Arenites, NATO ASI Series, (Vol. C148, pp. 333-363). Dordrecht: D. Reidel Publishing Company.

Dickinson, W. R., Beard, L. S., Brakenridge, G. R., Erjavec, J. L., Ferguson, R. C., Inman, K. F., et al. (1983). Provenance of North American Phanerozoic sandstones in relation to tectonic setting. Geological Society of America Bulletin, 94, 222-235.

Dickinson, W. R., \& Gehrels, G. E. (2009). Use of U-Pb ages of detrital zircons to infer maximum depositional ages of strata: A test against a Colorado Plateau Mesozoic database. Earth and Planetary Science Letters, 288, 115-125.

Dickinson, W. R., \& Seely, D. R. (1979). Structure and stratigraphy of forearc regions. The American Association of Petroleum Geologists Bulletin, 63, 2-28.

Dickinson, W. R., \& Suczek, C. A. (1979). Plate tectonics and sandstone compositions. AAPG, 63, 2164-2182.

Ding, L., Yang, D., Cai, F. L., Pullen, A., Kapp, P., Gehrels, G. E., et al. (2013). Provenance analysis of the mesozoic Hoh-Xil-Songpan-Ganzi turbidites in Northern Tibet: Implications for the tectonic evolution of the eastern paleo-tethys ocean. Tectonics, 32, 34-48. https://doi. org/10.1002/tect.20013

Dong, C. Y., Li, C., Wan, Y. S., Wang, W., Wu, Y. W., Xie, H. Q., \& Liu, D. Y. (2011). Detrital zircon age model of Ordovician Wenquan quartzite south of Lungmuco-Shuanghu suture in the Qiangtang area, Tibet: Constraint on tectonic affinity and source regions. Science China Earth Sciences, 54, 1034-1042.

Fan, J. J., Li, C., Wang, M., Xie, C. M., \& Xu, W. (2015). Features, provenance, and tectonic significance of Carboniferous-Permian glacial marine diamictites in the Southern Qiangtang-Baoshan block, Tibetan Plateau. Gondwana Research, 28, 1530-1542.

Fan, J. J., Li, C., Xie, C. M., Liu, Y. M., Xu, J. X., \& Chen, J. W. (2017). Remnants of late Permian-Middle Triassic ocean islands in northern Tibet: Implications for the late-stage evolution of the Paleo-Tethys Ocean. Gondwana Research, 44, 7-21.

Folk, R. L., Andrews, P. B., \& Lewis, D. W. (1970). Detrital sedimentary rockclassification and nomenclature for use in New Zealand. New Zealand Journal of Geology andGeophysics, 13(4), 937-968.

Fu, X. G., Wang, J., Tan, F. W., Chen, M., \& Chen, W. B. (2010). The Late Triassic rift-related volcanic rocks from eastern Qiangtang, northern Tibet (China): Age and tectonic implications. Gondwana Research, 17, 135-144.

Gao, R., Chen, C., \& Lu, Z. W. (2013). New constraints on crustal structure and Moho topography in central Tibet revealed by SinoProbe deep seismic refection profiling. Tectonophysics, 606, 160-170.

Gazzi, P. (1966). Le Arenarie del Flysche Sopracretaceo dell'Appennino Modenese: Correlazioni con il Flysch di Monghidoro. Mineralogica e Petrografica Acta, 12, 69-97.

Gehrels, G., Kapp, P., De Celles, P., Pullen, A., Blakey, R., Weislogel, A., et al. (2011). Detrital zircon geochronology of pre-Tertiary strata in the Tibetan-Himalayan orogen. Tectonics, 30, TC5016. https://doi.org/10.1029/2011TC002868

Geng, Q. R., Peng, Z. M., \& Zhang, Z. (2012). New advances in the study of Carboniferous-Permian paleontology in GuoganjianianshanRongma area of Qiangtang region, Tibetan Plateau. Geological Bulletin of China, 31(4), 510-520.

Guillaume, B., Pochat, S., Monteux, J., Husson, L., \& Choblet, G. (2016). Can eustatic charts go beyond first order? Insights from the Permian-Triassic. Lithosphere, L523, 1.

Haq, B. U., \& Al-Qahtani, A. M. (2005). Phanerozoic cycles of sea-level changes on the Arabian Platform. GeoArabia, 10(2), 127-160.

Haq, B. U., \& Schutter, S. R. (2008). Phanerozoic cycles of sea-level changes. Science, 322(5898), 64-68.

Hu, P. Y., Li, C., Wu, Y. W., Xie, C. M., Wang, M., \& Li, J. (2014). Opening of the Longmu Co-Shuanghu-Lancangjiang ocean: Constraints from plagiogranites. Chinese Science Bulletin, 59(20), 1992-2003.

Hu, P. Y., Zhai, Q. G., Jahn, B. M., Wang, J., Li, C., Lee, H. Y., \& Tang, S. H. (2015). Early Ordovician granites from the South Qiangtang terrane, northern Tibet: Implications for the early Paleozoic tectonic evolution along the Gondwanan proto-Tethyan margin. Lithos, 220-223, 318-338.

Ji, Z. S., Yao, J. X., \& Wu, G. C. (2010). Discovery of Late Triassic coral fossils at the Guoganjianian Mountain in the Qiangtang central uplift, north Tibet and its geological significances. Acta Geologica Sinica, 84(8), 1095-1104.

Jiang, Q. Y., Li, C., Su, L., Hu, P. Y., Xie, C. M., \& Wu, H. (2015). Carboniferous arc magmatism in the Qiangtang area, northern Tibet: Zircon U-Pb ages, geochemical and Lu-Hf isotopic characteristics, and tectonic implications. Journal of Asian Earth Sciences, 100, $132-144$.

Kapp, P., DeCelles, P. G., Leier, A. L., Fabijanic, J. M., He, S., Pullen, A., et al. (2007). The Gangdese retroarc thrust belt revealed. GSA Today, 17(7), 4

Kapp, P., Yin, A., Manning, C. E., Harrison, T. H., \& Taylor, M. H. (2003). Tectonic evolution of the early Mesozoic blueschist-bearing Qiangtang metamorphic belt, central Tibet. Tectonics, 22(4), 1043. https://doi.org/10.1029/2002TC001383

Kapp, P., Yin, A., Manning, C. E., Murphy, M., Harrison, T. M., \& Spurlin, M. (2000). Blueschist-bearing metamorphic core complexes in the Qiangtang block reveal deep crustal structure of northern Tibet. Geology, 28(1), 19.

Lehrmann, D. J., Minzoni, M., Li, X. W., Yu, M. Y., Payne, J. L., Kelley, B. M., et al. (2012). Triassic oolites of the Nanpanjiang Basin, south China: Facies architecture, giant ooids, and diagenesis-Implications for hydrocarbon reservoirs. AAPG Bulletin, 96(8), $1389-1414$.

Leier, A. L., DeCelles, P. G., Kapp, P., \& Ding, L. (2007). The Takena Formation of the Lhasa terrane, southern Tibet: The record of a Late Cretaceous retroarc foreland basin. Geological Society of America Bulletin, 119(1-2), 31-48.

Li, C. (1987). The Longmucuo-Shuanghu-Lancangjiang plate suture and the north boundary of distribution of GondwanafaciesPermoCarboniferous system in northern Xizang, China [in Chinese with English abstract]. Journal of Changchun College of Geology, 17, $156-162$.

Li, Z. X., Bogdanova, S. V., Collins, A. S., Davidson, A., Waele, B. D., Ernst, R. E., et al. (2008). Assembly, configuration, and break-up history of Rodinia: A synthesis. Precambrian Research, 160(1-2), 179-210. https://doi.org/10.1016/j.precamres.2007.04.021

Li, C., Chen, L. R., Hu, K., Yang, Z. R., \& Hong, Y. R. (1995). Study on the Paleo-Tethys suture zone of Lungmu Co-Shuanghu, Tibet, (pp. 1-83). Beijing: Geological Publishing House.

Li, C., Chen, L. R., Xu, F., Zhai, Q. G. \& Zhang, Y. C. (2006). Geologic map of the Mayer Kangri sheet (scale 1:250 000). Institute of geological survey of Jilin University.

Li, C., Huang, X. P., \& Zhai, Q. G. (2006). The Longmu Co-Shuanghu-Jitang plate suture and the northern boundary of Gondwanaland in the Qinghai-Tibet plateau [in Chinese with English abstract]. Earth Science Frontiers, 13(4), 136-147.

Li, X. H., Li, Z. X., He, B., Li, W. X., Li, Q. L., Gao, Y. Y., \& Wang, X. C. (2012). The Early Permian active continental margin and crustal growth of the Cathaysia Block: In situ U-Pb, Lu-Hf and O isotope analyses of detrital zircons. Chemical Geology, 328, 195-207. 
Li, G. M., Li, J. X., Zhao, J. X., Qin, K. Z., Cao, M. J., \& Evans, N. J. (2015). Petrogenesis and tectonic setting of Triassic granitoids in the Qiangtang terrane, central Tibet: Evidence from U-Pb ages, petrochemistry and Sr-Nd-Hf isotopes. Journal of Asian Earth Sciences, 105, 443-453.

Li, L., Meng, Q., Pullen, A., Garzione, C. N., Wu, G., Wang, Y., et al. (2014). Late Permian-early Middle Triassic back-arc basin development in West Qinling, China. Journal of Asian Earth Sciences, 87, 116-129.

Li, Y. L., Wang, C. S., Dai, J. G., Xu, G. Q., Hou, Y. L., \& Li, X. H. (2015). Propagation of the deformation and growth of the TibetanHimalayan orogen: A review. Earth-Science Reviews, 143, 36-61.

Li, D., Wang, G. H., Gao, J. H., Yuan, G. L., Zhou, J., Fang, D. R., et al. (2019). The continental subduction in the evolution of central Qiangtang mélange belt and its tectonic significance. International Geology Review. International Geology Review, 61(9), 1143-1170.

Li, Y. J., Wu, H. R., Li, H. S., \& Song, D. L. (1997). Discovery of Radiolarians in the Amugang and Chasang groups and Lugu Formation in Northern Tibet and some related geological problems. Geological Review, 43(3), 251-256.

Li, C., Xie, C. M., Wang, M., Wu, Y. W., Hu, P. Y., Zhang, X. Z., \& Xu, F. (2016). Qiangtang geology, (pp. 1-182). Beijing: Geological Publishing House.

Li, C., Zhai, Q. G., Dong, Y. S., \& Huang, X. P. (2006). Discovery of eclogite and its geological significance in Qiangtang area, central Tibet [in Chinese with English abstract]. Chinese Science Bulletin, 51, 1095-1100.

Li, C., Zhai, Q. G., Dong, Y. S., Yu, J. J., \& Huang, X. P. (2007). Establishment of the Upper Triassic Wanghuling Formation at Guoganjianian Mountain, central Qiangtang, Qinghai-Tibet plateau, and its significance. Geological Bulletin of China, 26(8), $1003-1008$.

Li, C., Zhai, Q. G., Chen, W., Dong, Y. S., \& Yu, J. J. (2007). Geological evidence of the closure of Longmu Co-shuanghu suture, QianghaiTibet plateau: Ar-Ar and zircon SHRIMP geochronology from ophiolite and rhyolite in Guoganjianian. Acta Petrologica Sinica, 23(5), 911-918.

Li, C., Zhai, Q. G., Chen, W., Yu, J. J., \& Huang, X. P. (2006). Ar-Ar chronometry of the eclogite from central Qiangtang area, Qinghai-Tibet Plateau [in Chinese with English abstract]. Acta Petrologica Sinica, 22(12), 2843-2849.

Li, J. C., Zhao, Z. B., Zheng, Y. L., Yuan, G. L., Liang, X., Wang, G. H., \& Liu, X. (2015). The magmatite evidences in southern Qiangtang for paleo-Tethys ocean subducting collision: Gangtang-co granites in Rongma, Tibet. Acta Petrologica Sinica, 31(7), $2078-2088$.

Liang, D. Y., Nie, Z. T., \& Guo, T. Y. (1983). Permo-Carboniferous Gondwana-Tethys facies in southern Karakoran, Ali, Xizang (Tibet) [in Chinese with English abstract]. Earth Science-Journal of Wuhan College of Geology, 1, 9-25.

Liang, X., Wang, G. H., Yang, B., Ran, H., Zheng, Y. L., Du, J. X., \& Li, L. G. (2017). Stepwise exhumation of the Triassic Lanling highpressure metamorphic belt in Central Qiangtang, Tibet: Insights from a coupled study of metamorphism, deformation, and geochronology. Tectonics, 36, 652-670. https://doi.org/10.1002/2016TC004455

Liang, X., Wang, G. H., Yuan, G. L., \& Che, X. C. (2015). Mesozoic and Cenozoic deformations in the Raggyorcaka area, Tibet: Implications for the tectonic evolution of the North Qiangtang terrane. Journal of the Geological Society, London, 172, 614-623.

Liang, X., Wang, G. H., Yuan, G. L., \& Liu, Y. (2012). Structural sequence and geochronology of the QomoRi accretionary complex, Central Qiangtang, Tibet: Implications for the Late Triassic subduction of the Paleo-Tethys Ocean. Gondwana Research, 22, 470-481.

Liu, B. P., Feng, Q. L., Chonglakmani, C., \& Helmcke, D. (2002). Framework of Paleotethyan archipelago ocean of western Yunnan and its elongation towards North and South [in Chinese with English abstract]. Earth Science Frontiers, 9, 163-164.

Liu, S. F., Nummedal, D., \& Liu, L. J. (2011). Migration of dynamic subsidence across the Late CretaceousUnited States Western Interior Basin in response to Farallon plate subduction. Geology, 39(6), 555-558. https://doi.org/10.1130/G31692.1

Liu, S. F., Nummedal, D., Yin, P. G., \& Luo, H. J. (2005). Linkage of Sevier thrust episodes and Late Cretaceous megasequences across southern Wyoming (USA). Basin Research, 17, 487-506. https://doi.org/10.1111/j.1365-2117.2005.00277.x

Liu, T., Zhai, Q. G., Wang, J., Su, L., Kang, Z., \& Suolang, C. L. (2013). LA-ICP-MS zircon U-Pb age of high-grade metamorphic rocks from the Qiangtang Basin, northern Tibet, and its geological implications. Geological Bulletin of China, 32(11), 1691-1703.

Liu, Y., \& Sun, K. Q. (2008). Study on the Permian paleophytogeographical provinces in Xizang (Tibet). Geological Review, 54(3), 290-295.

Liu, Y. M., Li, C., Xie, C. M., Fan, J. J., Wu, H., Jiang, Q. Y., \& Li, X. (2016). Cambrian granitic gneiss within the central Qiangtang terrane, Tibetan Plateau: Implications for the early Palaeozoic tectonic evolution of the Gondwanan margin. International Geological Review, 58(9), 1043-1063.

Liu, Z. F., \& Wang, C. S. (2001). Facies analysis and depositional systems of Cenozoic sediments in the Hoh Xil basin, northern Tibet. Sedimentary Geology, 140, 251-270.

Lu, B., Liu, C. Y., Liu, Z., \& Li, Y. T. (2001). Basement formation and structural features of the Qiangtang basin and their implications [in Chinese with English abstract]. Seismology and Geology, 23, 510-517.

Lu, Z. W., Gao, R., Li, Y. T., Xue, A. M., Li, Q. S., Wang, H. Y., et al. (2013). The upper crustal structure of the Qiangtang Basin revealed by seismic reflection data. Tectonophysics, 606, 171-177.

Ludwig, K.R. (2008). Isoplot 3.6, (pp.77). Berkeley geochronology center, special publication 4.

Manea, V. C., Pérez-Gussinyé, M., \& Manea, M. (2012). Chilean flat slab subduction controlled by overriding plate thickness and trench rollback. Geology, 40(1), 35-38.

Maravelis, A. G., Boutelier, D., Catuneanu, O., Seymour, K. S., \& Zelilidis, A. (2016). A review of tectonics and sedimentation in a forearc setting: Hellenic Thrace basin, north Aegean Sea and northern Greece. Tectonophysics, 674, 1-19.

Metcalfe, I. (2013). Gondwana dispersion and Asian accretion: Tectonic and palaeogeographic evolution of eastern Tethys. Journal of Asian Earth Sciences, 66, 1-33.

Miall, A. D. (1978). Lithofacies types and vertical profile models in braided river deposits: A summary. In A. D. Miall (Ed.), Fluvial Sedimentology, Mem. Can. Soc. petrol. Geol., (Vol. 5, p. 597-604).

Miall, A. D. (1985). Architectural-element analysis: A new method of facies analysis applied to fluvial deposits. Earth-Science Reviews, 22, 261-308.

Nichols, G. (2009). Sedimentology and Stratigraphy, (2nd ed.pp. 199-212). Chichester: Wiley-Blackwell.

Noda, A. (2016). Forearc basins: Types, geometries, and relationships to subduction zone dynamics. GSA Bulletin, 128(5-6), 879-895 https://doi.org/10.1130/B31345.1

O'Driscoll, L. J., Richards, M. A., \& Humphreys, E. D. (2012). Nazca-South America interactions and the late Eocene-late Oligocene flatslab episode in the central Andes. Tectonics, 31, TC2013. https://doi.org/10.1029/2011TC003036

Orme, D. A., \& Laskowski, A. K. (2016). Basin analysis of the Albian-Santonian Xigaze forearc, Lazi Region, south-central Tibet. Journal of Sedimentary Research, 86, 894-913.

Orme, D. A., Carrapa, B., \& Kapp, P. (2015). Sedimentology, provenance and geochronology of the upper Cretaceous-lower Eocene western Xigaze forearc basin, southern Tibet. Basin Research, 27, 387-411. 
Pan, G. T., Wang, L. Q., \& Li, R. S. (2012). Tectonic evolution of the Qinghai-Tibet Plateau. Journal of Asian Earth Sciences, 53, 3-14.

Peng, H., Li, C., Xie, C. M., Wang, M., Jiang, Q. Y., \& Chen, J. W. (2014). Riwanchaka Group in central Qiangtang Basin, the Tibetan Plateau: Evidence from detrital zircons. Geological Bulletin of China. Geological Bulletin of China, 33(11), 1715-1727.

Peng, Z. M., Geng, Q. R., Zhang, Z., Jia, B. J., \& Diao, Z. Z. (2011). SHRIMP zircon U-Pb ages and their geological implications for the metamorphic rocks in the Qiangtang Basin. Sedimentary Geology and Tethyan Geology, 3(4), 97-103.

Pullen, A., \& Kapp, P. (2014). Mesozoic tectonic history and lithospheric structure of the Qiangtang terrane: Insights from the Qiangtang metamorphic belt, central Tibet.. In J. Nie, B. K. Horton \& G. D. Hoke, (Eds.), Toward an Improved Understanding of Uplift Mechanisms and the Elevation History of the Tibetan Plateau: Geological Society of America Special Paper(Vol. 507). https://doi.org/10.1130/2014.2507 (04)

Pullen, A., Kapp, P., Gehrels, G. E., Ding, L., \& Zhang, Q. H. (2011). Metamorphic rocks in central Tibet: Lateral variations and implications for crustal structure. Geological Society of America Bulletin, 123, 585-600.

Pullen, A., Kapp, P., Gehrels, G. E., Vervoort, J. D., \& Ding, L. (2008). Triassic continental subduction in central Tibet and Mediterraneanstyle closure of the Paleo-Tethys Ocean. Geology, 36, 351-354.

Ramos, V. A., \& Folguera, A. (2009). Andean flat-slab subduction through time. Geological Society, London, Special Publications, 327, 31-54.

Searle, M. P., Elliott, J. R., \& Phillips, R. J. (2011). Crustal-lithospheric structure and continental extrusion of Tibet. Journal of the Geological Society, 168(3), 633-672.

Shi, D., Zhao, W., Brown, L., Nelson, D., Zhao, X., Kind, R., et al. (2004). Detection of southward intracontinental subduction of Tibetan lithosphere along the Bangong-nujiang suture by p-to-s converted waves. Geology, 32(3), 209-212.

Sickmann, Z. T., Schwartz, T. M., \& Graham, S. A. (2018). Refining stratigraphy and tectonic history using detrital zircon maximum depositional age: An example from the Cerro Fortaleza Formation, Austral Basin, southern Patagonia. Basin Research, 1-22.

Song, P. P., Ding, L., Li, Z. Y., Lippert, P. C., Yang, T. S., Zhao, X. X., et al. (2015). Late Triassic paleolatitude of the Qiangtang block: Implications for the closure of the Paleo-Tethys Ocean. Earth and Planetary Science Letters, 424, 69-83.

Song, P. P., Ding, L., Li, Z. Y., Lippert, P. C., \& Yue, Y. H. (2017). An early bird from Gondwana: Paleomagnetism of Lower Permian lavas from northern Qiangtang (Tibet) and the geography of the Paleo-Tethys. Earth and Planetary Science Letters, 475, 119-133.

Tucker, M. E. (2011). Sedimentary rocks in the field: A practical guide, 1-269, (fourth ed.). Chichester: John Wiley \& Sons, Ltd.

Walker, R. G. (1978). Deep-water sandstone facies and ancient submarine fans: Models for exploration for stratigraphic traps. $A A P G$ Bulletin, 62(5), 239-263.

Wang, B. D., Wang, L. Q., Chen, J. L., Liu, H., Yin, F. G., \& Li, X. B. (2017). Petrogenesis of Late Devonian-Early Carboniferous volcanic rocks in northern Tibet: New constraints on the Paleozoic tectonic evolution of the Tethyan Ocean. Gondwana Research, 41, 142-156.

Wang, C. S., \& Yin, H. S. (2001). The geological evolution and prospective oil and gas assessment of the Qiangtang basin in northern Tibetan plateau, (pp. 1-168). Beijing: Geological Publishing House.

Wang, G. H., Han, F. L., Yang, Y. J., Li, Y. Q., \& Cui, J. L. (2009). Discovery and geologic significance of Late Paleozoic accretionary complexes in Central Qiangtang, northern Tibet, China [in Chinese with English abstract]. Geological Bulletin of China, 28, $1181-1187$.

Wang, J., Fu, X. G., \& Chen, W. R. (2008). Geochronology and geochemistry of the Woruoshan volcanics in north Qiangtang: Implications for the regional Triassic magmatic-sedimentary evolution [in Chinese with English abstract]. Science in China (series D), $38,33-43$.

Wang, J., Tan, F. W., \& Li, Y. L. (2004). The potential of the oil and gas resources in major sedimentary basins on the Qinghai-Tibet plateau, (pp. 1-98). Beijing: Geological Publishing House.

Wang, J., Wang, Z. J., Chen, W. X., Fu, X. G., \& Chen, M. (2007). New evidences for the age assignment of the NadiKangri Formation in the North Qiangtang basin, northern Tibet, China [in Chinese with English abstract]. Geological Bulletin of China, 26, 404-409.

Wang, L. Q., Pan, G. T., Li, C., Dong, Y. S., Zhu, D. C., Yuan, S. H., \& Zhu, T. X. (2008). SHRIMP U-Pb zircon dating of Eopaleozoic cumulate in Guoganjianian Mt. from central Qiangtang area of northern Tibet-Considering the evolvement of Proto-and Paleo-Tethys [in Chinese with English abstract]. Geological Bulletin of China, 27, 2045-2056.

Wang, Y. J., Zhang, F. F., Fan, W. M., Zhang, G. W., Chen, S. Y., Cawood, P. A., \& Zhang, A. M. (2010). Tectonic setting of the South China Block in the early Paleozoic: Resolving intracontinental and ocean closure models from detrital zircon U-Pb geochronology. Tectonics, 29, TC6020. https://doi.org/10.1029/2010TC002750

Wang, Y. X., Liang, X., Wang, G. H., Yuan, G. L., \& Bons, P. D. (2018). Mayer Kangri metamorphic complexes in Central Qiangtang (Tibet, western China): Implications for the Triassic-early Jurassic tectonics associated with the Paleo-Tethys Ocean. International Journal of Earth Sciences, 107(2), 757-776. https://doi.org/10.1007/s00531-017-1526-1

Wei, W., Unsworth, M., Jones, A., Booker, J., Tan, H., Nelson, D., et al. (2001). Detection of widespread fluids in the Tibetan crust by magnetotelluric studies. Science, 292(5517), 716-718.

Wen, S. X. (1979). The discovery of new strata in north Tibet. Acta Stratigraphica Sinica, 3(2), 150-156.

Wu, G. C., Yao, J. X., \& Ji, Z. S. (2009). The Late Carboniferous Fusulinids in the central part of northern Qiangtang, Tibet, China [in Chinese with English abstract]. Geological Bulletin of China, 28, 1276-1280.

Wu, H., Li, C., Chen, J. W., \& Xie, C. M. (2015). Late Triassic tectonic framework and evolution of Central Qiangtang, Tibet, SW China. Lithosphere, 8(2), 141-149.

Wu, Y. W., Li, C., Xie, C. M., Wang, M., \& Hu, P. Y. (2010). Petrology and geochronology of Guoganjianianshan Permian ophiolite in central Qiangtang, Qinghai-Tibet Plateau, China [in Chinese with English abstract]. Geological Bulletin of China, 29, 1773-1779.

Xie, C. M., Li, C., Ren, Y. S., Wang, M., \& Su, L. (2018). Detrital provenance, depositional environment, and palaeogeographic implications of Lower Triassic marine sediments in central Tibet. International Geology Review, 60(4), 418-430.

Yin, A., \& Harrison, T. M. (2000). Geologic evolution of the Himalayan-Tibetan Orogen. Annual Review of Earth and Planetary Sciences, 28 , 211-280.

Zhai, Q. G., Jahn, B. M., Su, L., Ernst, R. E., Wang, K. L., Zhang, R. Y., et al. (2013). SHRIMP zircon U-Pb geochronology, geochemistry and Sr-Nd-Hf isotopic compositions of a mafic dyke swarm in the Qiangtang terrane, northern Tibet and geodynamic implications. Lithos, $174,28-43$.

Zhai, Q. G., Jahn, B. M., Su, L., Wang, J., Mo, X. X., Lee, H. Y., et al. (2013). Triassic arc magmatism in the Qiangtang area, northern Tibet: Zircon $\mathrm{U}-\mathrm{Pb}$ ages, geochemical and Sr-Nd-Hf isotopic characteristics, and tectonic implications. Journal of Asian Earth Sciences, 63, 162-178.

Zhai, Q. G., Jahn, B. M., Wang, J., Hu, P. Y., Chung, S. L., Lee, H. Y., et al. (2016). Oldest Paleo-Tethyan ophiolitic mélange in the Tibetan Plateau. GSA Bulletin, 128(3/4), 355-373. https://doi.org/10.1130/B31296.1

Zhai, Q. G., Jahn, B. M., Wang, J., Su, L., Mo, X. X., Wang, K. L., et al. (2013). The Carboniferous ophiolite in the middle of the Qiangtang terrane, northern Tibet: SHRIMP U-Pb dating, geochemical and Sr-Nd-Hf isotopic characteristics. Lithos, 168-169, 186-199. 
Zhai, Q. G., Jahn, B. M., Zhang, R. Y., Wang, J., \& Su, L. (2011). Triassic subduction of the Paleo-Tethys in northern Tibet, China: Evidence from the geochemical and isotopic characteristics of eclogites and blueschists of the Qiangtang Block. Journal of Asian Earth Sciences, 42 , 1356-1370.

Zhai, Q. G., Zhang, R. Y., Jahn, B. M., Li, C., Song, S. G., \& Wang, J. (2011). Triassic eclogites from central Qiangtang, northern Tibet, China: Petrology, geochronology and metamorphic P-T path. Lithos, 125, 173-189.

Zhang, K. J., Cai, J. X., \& Zhang, Y. X. (2006). Eclogites from central Qiangtang, northern Tibet (China) and tectonic implications. Earth and Planetary Science Letters, 245, 722-727.

Zhang, K. J., Tang, X. C., Wang, Y., \& Zhang, Y. X. (2011). Geochronology, geochemistry, and Nd isotopes of early Mesozoic bimodal volcanism in northern Tibet, western China: Constraints on the exhumation of the central Qiangtang metamorphic belt. Lithos, 121, 167-174.

Zhang, K. J., Zhang, Y. X., Li, B., Zhu, Y. T., \& Wei, R. Z. (2006). The blueschist-bearing Qiangtang metamorphic belt (northern Tibet, China) as an in situ suture zone: Evidence from geochemical comparison with the Jinsa suture. Geology, 34, 493-496.

Zhang, K. J., Zhang, Y. X., Tang, X. C., \& Xia, B. (2012). Late Mesozoic tectonic evolution and growth of the Tibetan plateau prior to the Indo-Asian collision. Earth-Science Reviews, 114, 236-249.

Zhang, X. Z., Dong, Y. S., Wang, Q., Dan, W., Zhang, C. F., Deng, M. R., et al. (2016). Carboniferous and Permian evolutionary records for the Paleo-Tethys Ocean constrained by newly discovered Xiangtaohu ophiolites from central Qiangtang, central Tibet. Tectonics, 35 , 1670-1686. https://doi.org/10.1002/2016TC004170

Zhang, X. Z., Dong, Y. S., Wang, Q., Dan, W., Zhang, C. F., Xu, W., \& Huang, M. L. (2017). Metamorphic records for subduction erosion and subsequent underplating processes revealed by garnet-staurolite-muscovite schists in central Qiangtang, Tibet. Geochemistry, Geophysics, Geosystems, 18, 1-14. https://doi.org/10.1002/2016GC006576

Zhang, Y. C., Shen, S. Z., Shi, G. R., Wang, Y., Yuan, D. X., \& Zhang, Y. J. (2012). Tectonic evolution of the Qiangtang block, northern Tibet during the late Cisuralian (late early Permian): Evidence from fusuline fossil records. Palaeogeography Palaeoclimatology Palaeoecology, 350-352, 139-148.

Zhang, Y. C., Shen, S. Z., Zhai, Q. G., Zhang, Y. J., \& Yuan, D. X. (2015). Discovery of a Sphaeroschwagerina fusuline fauna from the Raggyorcaka Lake area, northern Tibet: Implications for the origin of the Qiangtang Metamorphic Belt. Geological Magazine, $153(3), 1-7$.

Zhao, Z., Bons, P. D., Wang, G., Soesoo, A., \& Liu, Y. (2015). Tectonic evolution and high-pressure rock exhumation in the Qiangtang Terrane, central Tibet. Solid Earth, 6, 457-473.

Zhao, Z. B., Bons, P. D., Wang, G. H., Liu, Y., \& Zheng, Y. L. (2014). Origin and pre-Cenozoic evolution of the south Qiangtang basement, central Tibet. Tectonophysics, 623, 52-66.

Zhao, Z. Z., \& Li, Y. T. (2000). Conditions of petroleum geology of the Qiangtang basin of the Qinghai-Tibet plateau [in Chinese with English abstract]. Acta Geologica Sinica, 74, 661-665.

Zheng, Y. L., Wang, G. H., Guo, Z. W., Liang, X., Yuan, G. L., Wang, H. D., et al. (2015). The record of the Pan-African and the Indosinian tectono-thermal event in Qiangtang terrane, northern Tibet: Evidence from geochemical characteristics and U-Pb geochronology of the metamorphic complex in Ejiumai area. Acta Petrologica Sinica, 31(4), 1137-1152.

Zhu, D. C., Zhao, Z. D., Niu, Y. L., Dilek, Y., Hou, Z. Q., \& Mo, X. X. (2013). The origin and pre-Cenozoic evolution of the Tibetan Plateau. Gondwana Research, 23, 1429-1454

Zhu, D. C., Zhao, Z. D., Niu, Y. L., Dilek, Y., \& Mo, X. X. (2011). Lhasa terrane in southern Tibet came from Australia. Geology, 39, 727-730.

Zhu, T. X., Feng, X. T., Wang, X. F., \& Zhou, M. K. (2010). Late Triassic tectono-palaeogeography of the Qiangtang area on the QinghaiXizang Plateau. Sedimentary Geology and Tethyan Geology, 30(4), 1-10.

Zhu, T. X., Li, Z. L., Li, C., Feng, X. T., Zhang, Q. Y., Zhang, H. H., et al. (2005). New data of Triassic strata in the Shuanghu area, northern Tibet, China [in Chinese with English abstract]. Geological Bulletin of China, 24, 1127-1134.

Zhu, T. X., Zhang, Q. Y., Dong, H., Wang, Y. J., Yu, Y. S., \& Feng, X. T. (2006). Discovery of the Late Devonian and Late Permian radiolarian cherts in tectonic mélanges in the Cedo Caka area, Shuanghu, northern Tibet, China [in Chinese with English abstract]. Geological Bulletin of China, 25, 1413-1418. 